\title{
Sharing Economy: The Establishment of Organizational Identity Overtime, Considering Identify Claims and Legitimacy Granting
}

\author{
João Miguel Oliveira Cotrim, Ph.D. Cand. \\ ISCTE Business School \\ Prof. Dr. Francisco Nunes
}

Researcher, ISCTE Business School

\begin{abstract}
The Sharing Economy (SE) has been growing at an impressive rate across the globe (Cohen \& Kietzmann, 2014) and emerging as an innovative and rapidly growing sector of the economy (Hira \& Reilly, 2017), which attracted the attention of the scientific community. An increasing number of studies have been brought to light helping to document and analyze how SE manifests and evolves across economic systems, thus, contributing to refine and recast existing management theory (Mair \& Reischauer, 2017). Nevertheless, there still is a lack of a common understanding of SE and its underlying mechanisms (Knote \& Blohm, 2016). As an emergent category, SE has been contoured by being a mutant process, as it has been crafted by multiple and distinct temporal identity and legitimacy events, mechanisms and claims. Showing signs of being an on-going process of evolution, there is a constant need for further research to identify developments in the evolution of SE considering both identify claims (self-referential) and legitimacy (granted by stakeholders), which would offer additional comprehension about the SE phenomenon. The research addresses it by studying what is the role of SE in establishing the identity of organizations belonging to the field, considering both identify claims (selfreferential) and legitimacy (granted by stakeholders)? To answer the research question, the research was designed involving two components inspired on category creation studies (Durand \& Paolella, 2013; Glynn \& Navis, 2013; Navis \& Glynn, 2010; Kennedy \& Fiss, 2013; Kennedy et al., 2010; Lounsbury \& Rao, 2004; and Wry et al., 2014): 1) four prototypical SE organizations were selected, each of them belonging to Schor's (2014) four SE archetypes of activities: (i) Airbnb - peer-to-peer, for-profit activity -, (ii) Zipcar - business-to-peer, forprofit activity -, (iii) TimeBanks - peer-to-peer, non-profit - and (iv) Make: makerspaces - business-to-peer, non-profit. The content of the evolution of their identity claims was analyzed, using data from their public available reports, as well as, other secondary data available on-line; and 2) considering the same set of SE organizations, legitimacy evolution was analyzed considering how scientific community, investors, customers, media, other analysts and other interested audiences have been constructing category meaning to them, conferring the formation of SE categorical and organizational identities, and perceptions about the viability of their business models (Tripsas, 2009, as cited in Navis \& Glynn, 2010). In short, it was analyzed how stakeholders assess the viability of SE categories and organizations and can grant or withhold legitimacy to SE organizations (Zuckerman, 1999, as cited in Navis \& Glynn, 2010). This research presents a new layer on framing a detailed understanding of the SE field in its maturing dimension, thus, meeting Mair's and Reischauer's (2017) call for studying the SE, unpack and make sense of an inspiring and complex phenomenon and thereby advancing and sophisticate the existing theory.
\end{abstract}

Keywords: Sharing Economy; Identity Claims; Legitimacy Granting; Prototypical Organizations; Stakeholders.

\section{Introduction}

The Sharing Economy has been having a great boost and attracting great attention over the last few years from a vast variety of stakeholders. Along the process, it has been evaluated as (i) having a huge potential for creating new businesses and services that may allocate value more fairly bringing people together in new ways (Schor, 2014), (ii) involving millions 
or even billions of participants and (iii) capitalizing the existing assets while providing spillover effects in the economy (Bonciu \& Bâlgar, 2016).

This research main objective is to study how has the establishment of SE organizational identities been evolving overtime, considering identify claims and legitimacy granting.

\section{The Theoretical-Conceptual Framework}

The Sharing Economy (SE) is a relatively new phenomenon by way of technology standards (Zifkin, 2015), born of the Internet age (Belk, 2014), and in which you are not helping a friend for free but rather providing SE services to a stranger for money (Sundararajan, 2016). The commercial sharing services or "prototypical actors and practices" (Navis et al., 2012, p. 26) of SE allow people share resources in creative, new ways (Cohen \& Kietzmann, 2014). It's a new form of sweating underutilized assets, by building communities around them and turning consumers into providers (Varsavsky, cited in Silver, 2013). Its participants are being labeled as digital matching firms (ESA, 2016) and the sector is perceived to contour four main characteristics (Penn \& Wihbey, 2016): (a) they use information technology (IT systems) facilitate peer-to-peer transactions; (b) they rely on user-based rating systems for quality control; (c) they offer the workers who provide services via digital matching platforms flexibility in deciding their typical working hours; (d) to the extent that tools and assets are necessary to provide a service, digital matching firms rely on the workers using their own. It also has been seen by some as a label to broadly define the emergent ecosystem that is upending mature business models across the globe, while analysts argue that no single label can neatly encapsulate this movement, as for some the word "sharing" was a misnomer, a savvy-but-disingenuous spin on an industry they felt was more about monetary opportunism than altruism, while for others, more appropriate titles included the Trust Economy, Collaborative Consumption, the On-Demand or Peer-to-Peer Economy (PwC, 2015). These developments have started to challenge traditional thinking about how resources can and should be offered and consumed, supporting arguments that incremental improvements in our existing production and consumption systems are insufficient to transform our global economy toward sustainability (Lovins \& Cohen, 2011; Stead \& Stead, 2013).

As we see, SE has a novelty dimension associated with it, in the sense that it is an emergent category. Thus, it should be studied as an important phenomenon influencing the establishment of organizational identity and legitimacy in both forprofit and non-profit businesses/activities. We, therefore, propose a new layer of research on SE that gives light to its category construction, emphasizing the establishment of organizational identity overtime, considering both identify claims and legitimacy granting. This follows below.

The process of categorization has not only a component of "straightjacket" (in the sense of delimiting a particular practice to a narrow group of actors), but also a "generative" component of new identities, practices (Glynn \& Navis, 2013). That is, when a new (supposed) category appears, it can also give an opportunity to open a range of new actors, entities and practices. We therefore have two dimensions in this discussion: in the genesis of "categorizing" something, there is both the need to define boundaries very well (who is and who cannot be within that category) as well as the almost intrinsic possibility (just like any other new and emerging process) of being the generator of new ideas, practices, prototypes and actors (the "creativity ingredient"). Further, the greater the uncertainty, the greater the sociocultural "pressure" to find a category for that entity, actor, practice or activity. That is, one of the factors/determinants for categorization is the so-called "sociocultural urgency in reducing identity uncertainty".

Durand and Paolella (2013), on the other hand, advocate that the process of categorizing / categorization goes beyond the classical prototype theory (Rosch \& Mervis, 1975), also known as the model of categorical constraint, where there is a very disciplinary exercise with strict, rigid (like a straightjacket) classification of products/actors/industries depending on their perfect match with the key features of a given category prototype. The authors bring to light Redher's (2003a, 2003b) causal model and Barsalou's (1983) goal-derived categories (ad hoc categories) in justifying that categorizing also involves other mediating sub-variables, antecedents coming from external audiences: (i) "cognitive test of congruence" and (ii) "goal satisfying calculus". In other words, audiences may legitimate a given product as being part of a particular category depending on situational circumstances, and not so much on general pre-conceived constructions of what a category is. Because of this, there may be multi-category memberships, hybrid organizations, which may be classified as being part of multi-categories and not just one. Audiences (consumers), thus, play a determinant part in such process. The process of categorization is much multifaceted with multi-variables. Thus, categories do involve a disciplinary exercise (Rosch's and Mervis' prototype theory), but also a cognitive test of congruence (Redher's causal model theory), and a goal satisfying 
calculus (Barsalou's goal-derived categories theory). In other words, when theorizing on categorization, one should consider the "integration of codes, causal associations, and goals".

Complementary, Kennedy and Fiss (2013) urge a research that focuses on how categories emerge and fall out of use and acquire meaning and relevance, arguing that research on categories should upstream study how categories emerge and fall out (dissolute). And to find answers to that, it must be taken into account two distinctive but complementary antecedent dimensions: (1) the occasions and motivations for invoking categories (similar to Durand's and Paolella's argument is that ad hoc and nascent categories occur when they facilitate goals or explain the causes of specific situations), and (2) their meaning and encompassing ontologies (that is: it involves studying the changing meaning of existing categories or of new categories that are emerging or failing to emerge, and it involves studying the implications for encompassing ontologies).

Kennedy et al. (2010), in turn, stress the importance in this discussion of what they call category currency. Meaning: category construction is a dynamic process, where audiences "buy" or "dismiss" certain emergent category ("alternatives for consideration") and, depending on these "exchanges" of category acceptance and rejection (or "the changing value of conformity"), category construction takes form. Figure1 below, illustrates how category meaning is an ongoing/dynamic construction. There are eight possible ways/paths for changing category meaning.

Figure 1 - Eight Ways Category Meaning Can Change

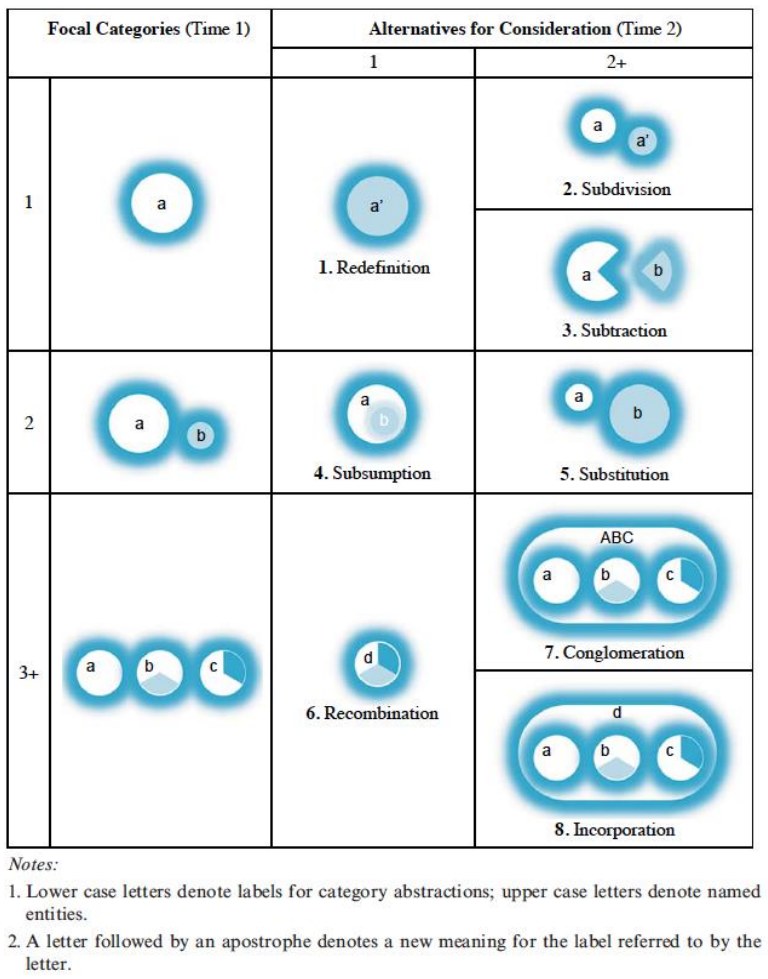

Source: Kennedy et al., 2010.

The discussion on categorization should also take into account Lounsbury's and Rao's (2004) contribution. The authors bring forward a new layer on the topic by introducing a new line of research, a new factor for category construction, durability, change and reconstruction: Political Power (from powerful producers) - "product categories are products of practical politics" (p. 991). Focusing on the role of industry media in institutional change, the authors argue that "industry media are not passive observers but important actors that promote stability by maintaining existing categories or creating new product categories from existing product categories so as to preserve comparability among firms (p. 972)". Moreover, 
they argue that "product categorization is importantly shaped by the politics of markets (...) and when powerful producers dominate a category, they can counteract the effects of performance variability and the influx of new entrants and encourage industry media to preserve the existing structure of categories" (p. 972). The authors' study suggests that "changes in product categories are not driven merely by technical processes but are fundamentally shaped by the politics of markets (...) product categories are fragile cognitive structures that can be brought down when there is high performance variability and new entrants embody variations and disturb the status quo" (p. 990). Categories are, therefore, just an outcome (like an interface) of the interplay of interests among industry media and producers. In this sense, "producers may pressure editors to locate them in product categories in which they look better (...) and cultural constructions such as product categories are implicated in a system of power" (p. 991-992).

The dimension of hybridization (Wry et al., 2014) should also be discussed. That is: organizations that span mix elements of multiple categories. "The category a firm starts in, how it hybridizes, and the degree to which this affects core versus peripheral identity markers may all affect how it is perceived" (p. 1309). Hybridization, thus, may not necessarily be negative ("overlooked" or "devalued"), but rather, organizations having mixed elements of multiple categories may generate positive reactions from external audiences.

Another component intrinsically associated with the process of categorization is legitimation. That is, how stakeholders confer the formation of categorical and organizational identities, and perceptions about the viability of their business models. Being a complex social process (Fligstein, 1997; Kennedy, 2008; Kennedy, Lo, and Lounsbury, 2010, cited in Navis and Glynn, 2010), it involves both entrepreneurial organizations and prospective resource providers, such as investors, analysts, customers, media, and other interested audiences, in the social construction of a market category's meaning, the formation of categorical and organizational identities, and perceptions about the viability of the business model (Tripsas, 2009, cited in Navis \& Glynn, 2010). Legitimating a new (market) category, on the other hand, involves consumers, industry analysts, stock market investors, or other audiences (Meyer and Rowan, 1977; DiMaggio and Powell, 1983, cited in cited in Navis \& Glynn, 2010) whose interests transcend individual organizations (Suchman, 1995, cited in Navis \& Glynn, 2010). Thus, it becomes critical to study the influence/role of audiences as they assess the viability of categories and organizations and can grant or withhold legitimacy (Zuckerman, 1999, cited in Navis \& Glynn, 2010). Also, with respect to the discussion around the SE, it becomes of particular importance to take into account how organizational identity affects audiences' evaluation of organizational performance, as Smith's (2011) study reveals that investors, for instance, are more likely to "allocate capital more readily to nonconforming hedge funds following periods of short-term positive performance". The more atypical a given organization is, the more likelihood of audiences to positively to respond to it and, thus, grant it legitimacy, which on the other hand, provides a distinct competitive advantage for that non-conforming organization. For the purposes of the present study, it becomes, therefore, important to understand how SE atypical organizations/entities have been assessed by audiences and stakeholders.

The legitimation of a new category, complementarily, depends on certain key determinants (Navis \& Glynn, 2010; Aldrich \& Fiol, 1994): (i) Sameness (or Close Substitution) - a new category exists when two or more products or services are perceived to be of the same type or close substitutes for each other in satisfying market demand; (ii) Distinctiveness - not all members are equivalent in the category; (iii) Credibility - given by actors external to the category, i.e., the interested audiences who judge its feasibility, credibility and appropriateness; (iv) Cognitive legitimation - relates to the level of public knowledge about a new activity (the highest form of cognitive legitimation is achieved when a new product, process, or service is taken for granted); (v) Sociopolitical legitimation - relates to the process by which key stakeholders, the general public, key opinion leaders, or governmental officials accept a venture as appropriate and right, given existing norms and laws. (the public acceptance of an industry, government subsidies to the industry, or the public prestige of its leaders).

In terms of the SE, and bearing in mind the determinants of Sameness (or Close Substitution) and Distinctiveness, Schor (2014) describes a number of services that are perceived to be of the same type in satisfying market demand that may be grouped together as members of the same category. She calls this as "four main types of SE activities". Below follows figure 2, which pinpoints SE activities according to the shared sameness with other category members and the individual distinctiveness from other members. 
Figure 2 - Archetypes of sharing economy activities

\begin{tabular}{|c|c|c|c|}
\cline { 3 - 4 } \multicolumn{2}{c|}{} & \multicolumn{2}{c|}{ Type of Provider } \\
\cline { 3 - 4 } Platform Orientation & Peer to Peer & Business to Peer \\
\cline { 2 - 4 } & Non-Profit & $\begin{array}{c}\text { Food Swaps } \\
\text { TimeBanks }\end{array}$ & Makerspaces \\
\cline { 2 - 4 } & For-Profit & $\begin{array}{c}\text { Relay Rides (transportation) } \\
\text { Airbnb (accommodation) } \\
\text { Uber (transportation) }\end{array}$ & Zipcar (transportation) \\
\hline
\end{tabular}

Source: Schor, 2014.

\section{Methodology}

\section{The Methods Used to Gather Data}

Bearing in mind the theoretical background exposed above, we pose the following Research Question and elaborate the respective Research Design:

Research Question (RQ): What is the role of SE in establishing the identity of organizations belonging to the field, considering both identify claims (self-referential) and legitimacy (granted by stakeholders, namely scientific community, investors, analysts, customers, media, and other interested audiences)? Is SE constraining the identity claims for the stake of legitimacy granting, or is SE acting as a general ambiguous category enabling divergence in identities and business models?

Research Design: this $R Q$ was answered by a design involving two components inspired on category creation studies (Durand \& Paolella, 2013; Glynn \& Navis, 2013; Navis \& Glynn, 2010; Kennedy \& Fiss, 2013; Kennedy et al., 2010; Lounsbury \& Rao, 2004; and Wry et al., 2014): 1) four prototypical SE organizations were selected, each of them belonging to Schor's (2014) four SE archetypes of activities. Respectively: (i) Airbnb - peer-to-peer, for-profit activity -, (ii) Zipcar business-to-peer, for-profit activity -, (iii) TimeBanks - peer-to-peer, non-profit - and (iv) Make: makerspaces - businessto-peer, non-profit. The evolution of their identity claims were content analyzed, using data from their publically available reports, as well as, other secondary data available on-line; and 2) considering the same set of SE organizations, legitimacy evolution was analyzed considering how scientific community, investors, analysts, customers, media, and other interested audiences have been constructing category meaning to them, conferring the formation of SE categorical and organizational identities, and perceptions about the viability of their business models (Tripsas, 2009, as cited in Navis \& Glynn, 2010). In short, it was analyzed how audiences assess the viability of SE categories and organizations and can grant or withhold legitimacy to SE organizations (Zuckerman, 1999, as cited in Navis \& Glynn, 2010).

\section{Results}

\section{Evolution of Identity Claims (self-referential) of Prototypical SE Organizations}

Table 1 below presents the results in a concise timeline of the key events related with the evolution of identity claims (selfreferential) of four prototypical SE organizations: Airbnb, Zipcar, Timebanks and Make: makerspaces.

Table 1 - Evolution of Identity Claims (self-referential) of Prototypical SE Organizations

Evolution of Identity Claims (self-referential) of Prototypical SE Organizations

$\begin{array}{lcl}\text { Prototypical } & \text { Architype of SE } \\ \text { Organization } & \text { activity } & \text { Milestone Facts \& Events }\end{array}$

$\begin{array}{ll}\text { Peer-to-peer } & \text { FALL 2007 } \\ \text { Brian Chesky and Joe Gebbia host the first guests of Airbedandbreakfast.com to make } \\ \text { rent money. }\end{array}$




$\begin{array}{cc}\begin{array}{c}\text { (continuation of } \\ \text { table 1) }\end{array} & \text { Peer-to-peer } \\ & \text { For-profit }\end{array}$

\section{MARCH 2008}

Airbed \& Breakfast officially launches during SXSW 2008 and makes two bookings.

\section{EARLY AUGUST 2008}

The formal Airbed \& Breakfast website launches for the Democratic National Convention to offer a solution for hotel room shortages and makes 80 bookings.

\section{AUGUST 25-28, 2008}

The Democratic National Convention in Denver.

\section{FALL 2008}

Chesky and Gebbia come up with the idea for Obama O's and Cap'n McCain's and sell \$30K worth.

\section{MARCH 2009}

Airbed \& Breakfast changes its name to Airbnb and expands beyond just rooms to apartments, houses, and vacation rentals.

\section{SEPTEMBER 2009}

First International meetup in Paris.

\section{NOVEMBER 2010}

Airbnb launches the iPhone app and Instant Book feature.

\section{SUMMER 2011}

Airbnb begins international expansion with opening of German office.

\section{MAY 2012}

Airbnb introduces the $\$ 1 \mathrm{M}$ Host Guarantee.

\section{JUNE 2012}

Airbnb launches the Wish Lists feature.

\section{NOVEMBER 7, 2012}

Airbnb offers free listings for Hurricane Sandy in partnership with the city of New York the official launch of the Disaster Relief tool.

\section{SUMMER 2013}

Airbnb moves headquarters to 888 Brannan San Francisco.

\section{JUNE 2014}

Airbnb hosts more than 100,000 guests during the Rio World Cup.

\section{JULY 2014}

Airbnb launches rebranding and introduces the Belo.

NOVEMBER 21-23, 2014

Airbnb Open in San Francisco - 1,500 hosts attend.

\section{MARCH 27, 2015}

Airbnb becomes the official alternative accommodation services supplier for 2016 Rio Olympic Games. 


\begin{tabular}{|c|c|c|}
\hline \multirow[t]{8}{*}{$\begin{array}{l}\text { (continuation of } \\
\text { table 1) }\end{array}$} & \multirow[t]{8}{*}{$\begin{array}{l}\text { Peer-to-peer } \\
\text { For-profit }\end{array}$} & $\frac{\text { APRIL 7, 2015 }}{\text { Airbnb launches in Cuba. }}$ \\
\hline & & $\begin{array}{l}\text { MAY } 25,2015 \\
\text { The White House appoints Brian Chesky as Presidential Ambassador for Global } \\
\text { Entrepreneurship. }\end{array}$ \\
\hline & & $\frac{\text { NOVEMBER } 12-14,2015}{\text { Airbnb welcomes } 6,000 \text { hosts at the Airbnb Open in Paris. }}$ \\
\hline & & $\begin{array}{l}\text { NOVEMBER 17-19, } 2016 \\
\text { At the Airbnb Open in LA, Airbnb announces the launch of Trips and welcomes 7,000 } \\
\text { attendees from over } 100 \text { countries. }\end{array}$ \\
\hline & & $\frac{\text { FEBRUARY } 5,2017}{\text { Airbnb launches the \#weaccept campaign in response to the refugee ban. }}$ \\
\hline & & $\begin{array}{l}\text { MARCH } 2017 \\
\text { Airbnb executives travel the globe meeting with the host community and world leaders to } \\
\text { expand Trips to } 20 \text { more cities. }\end{array}$ \\
\hline & & $\frac{\text { MARCH 21, } 2017}{\text { Airbnb launches their Chinese brand, Aibiying. }}$ \\
\hline & & $\begin{array}{l}\text { AS PER TODAY, AUGUST 3, } 2017 \\
\text { Airbnb stresses its identity claims in its website, by self-referring itself as: } \\
\text { "Founded in August of } 2008 \text { and based in San Francisco, California, Airbnb is a trusted } \\
\text { community marketplace for people to list, discover, and book unique accommodations } \\
\text { around the world - online or from a mobile phone or tablet"; } \\
\text { "Whether an apartment for a night, a castle for a week, or a villa for a month, Airbnb } \\
\text { connects people to unique travel experiences, at any price point, in more than } 65,000 \\
\text { cities and } 191 \text { countries. And with world-class customer service and a growing community } \\
\text { of users, Airbnb is the easiest way for people to monetize their extra space and showcase } \\
\text { it to an audience of millions". }\end{array}$ \\
\hline
\end{tabular}

\begin{tabular}{|c|c|c|}
\hline $\begin{array}{l}\text { Prototypical } \\
\text { Organization }\end{array}$ & $\begin{array}{l}\text { Architype of SE } \\
\text { activity }\end{array}$ & Milestone Facts \& Events \\
\hline \multirow{7}{*}{ z. zipcar. } & \multirow{7}{*}{$\begin{array}{l}\text { Business-to-peer } \\
\text { For-profit }\end{array}$} & $\underline{1999}$ \\
\hline & & 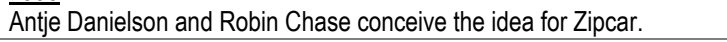 \\
\hline & & 2000 \\
\hline & & $\begin{array}{l}\text { The first Zipcar logo; } \\
\text { UUNF. The first 7incars debut on the streets of Boston and Cambridge }\end{array}$ \\
\hline & & $\frac{\text { SEPTEMBER } 2001}{\text { Zipcar arrives in Washington D.C. }}$ \\
\hline & & $\frac{\text { FEBRUARY } 2002}{\text { Zipcar arrives in New York city }}$ \\
\hline & & $\begin{array}{l}\frac{2003}{\text { The second Zipcar logo; }} \\
\text { JANUARY: Zipcar reaches 5,000 users. }\end{array}$ \\
\hline
\end{tabular}




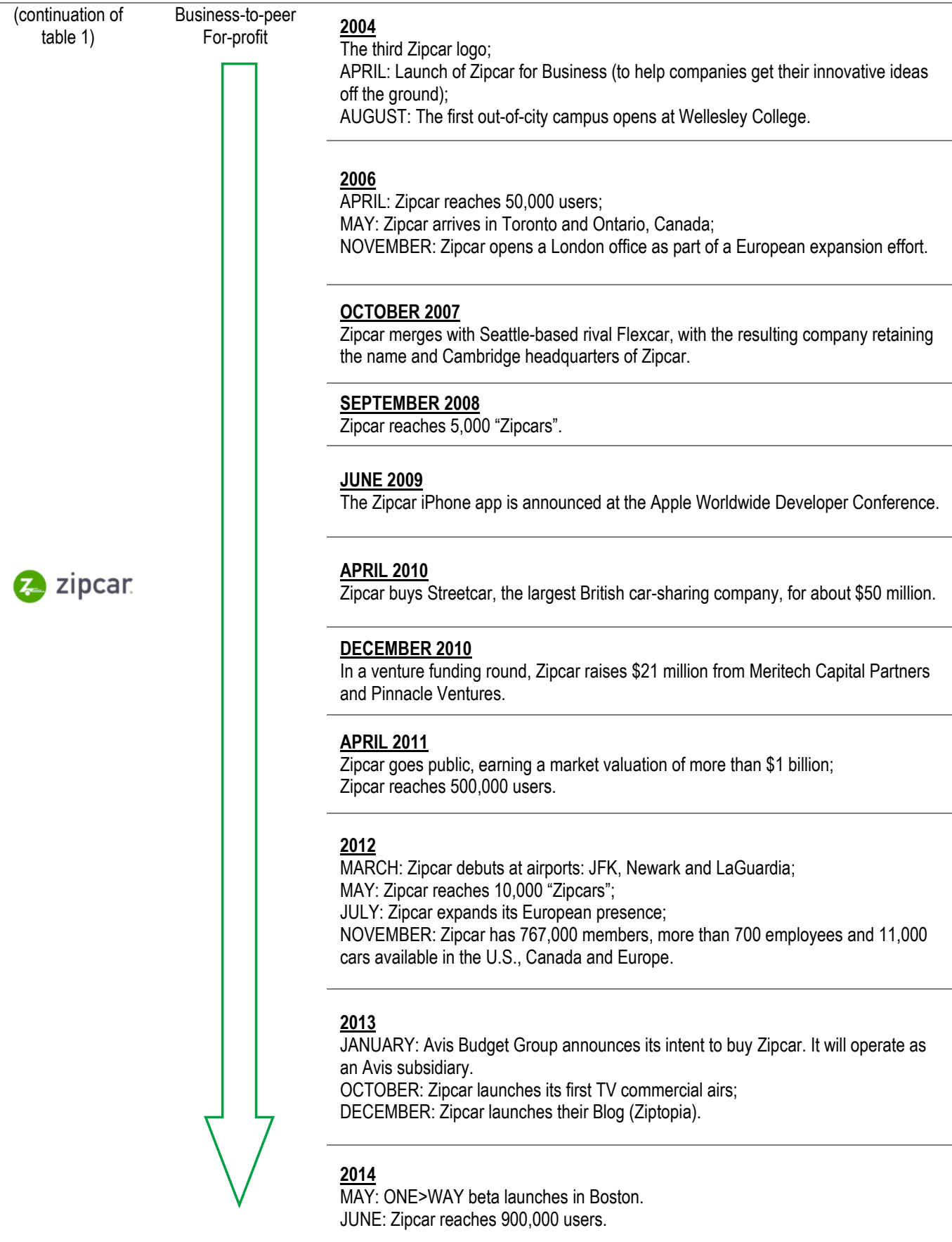




\begin{tabular}{|c|c|c|}
\hline $\begin{array}{c}\text { (continuation of } \\
\text { table 1) }\end{array}$ & $\begin{array}{c}\text { Business-to-peer } \\
\text { For-profit }\end{array}$ & 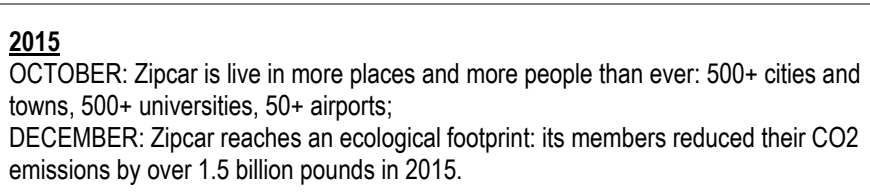 \\
\hline & & $\begin{array}{l}\text { NOVEMBER } 8,2016 \\
\text { Zipcar gives away free car rentals on American Election Day to encourage its } \\
\text { members to vote; } \\
\text { A Zipcar is reserved every } 6 \text { seconds. }\end{array}$ \\
\hline z. zipcar. & & $\begin{array}{l}\text { AS PER TODAY, AUGUST } 3, \mathbf{2 0 1 7} \\
\text { Zipcar stresses its identity claims in its website, by self-referring itself as: } \\
\text { "We've been around since } 1999 \text {. That was before Wikipedia, the Razr phone, and } \\
\text { the iPod. Whoa. With } 15 \text { years of collaboration and innovation under our (seat) belts, } \\
\text { we're working to make cities better places to live." } \\
\text { "It's been more than a decade since our founders sat in a café and decided to bring } \\
\text { the European car-sharing idea to North America. Once the wheels were in motion, it } \\
\text { was only a matter of time before some major changes helped grow a little car-sharing } \\
\text { company into the world's leading car-sharing network. Today, thanks to cool } \\
\text { technology, a member-driven user experience, and an amazing team of hands-on } \\
\text { car sharing enthusiasts, we are redefining the way this generation thinks about } \\
\text { alternative transportation"; } \\
\text { "We're not horn tooters, more like ambassadors for change. Zipcar isn't just about } \\
\text { the concept of car sharing; it's about the people who make it a reality: a team that } \\
\text { works hard, members who believe, and organizations that are making conscious } \\
\text { decisions for the future. We're gonna keep doing what we're doing, looking for ways } \\
\text { to make car sharing easier, faster, and better. We're not trying to rule the world, just } \\
\text { trying to give regular people - young and old, business types and family types - the } \\
\text { freedom to live life". }\end{array}$ \\
\hline
\end{tabular}

$\begin{array}{cc}\text { Prototypical } & \begin{array}{c}\text { Architype of SE } \\ \text { Organization }\end{array}\end{array}$

Milestone Facts \& Events

$\begin{array}{ll}\text { Peer-to-peer } & 1980 \text { (VERY EARLY DAYS) } \\ \text { Non-profit } & \begin{array}{l}\text { Dr. Edgar S. Cahn creates TimeBanking as a medium of exchange that would act as a way } \\ \text { to encourage and reward the work needed to build strong, resilient communities. }\end{array}\end{array}$

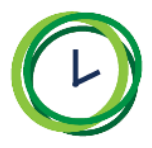

TimeBanks

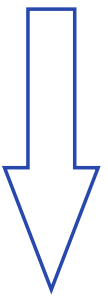

\section{1 (STILL VERY EARLY DAYS)}

Grace Hill Settlement House in St. Louis, MO became the first organization to use TimeBanking.

\section{5}

TimeBanks USA (TBUSA), a registered 501c3 headquartered in Washington D.C., was formed by Dr. Edgar Cahn to expand the knowledge and field of timebanking and its impact on individuals, youth, families, communities, the environment, and the world. 


\begin{tabular}{|c|c|c|}
\hline $\begin{array}{l}\text { (continuation of } \\
\text { table 1) }\end{array}$ & $\begin{array}{l}\text { Peer-to-peer } \\
\text { Non-profit }\end{array}$ & $\underline{1995-2017}$ \\
\hline & & $\begin{array}{l}\text { TBUSA has fostered the spread of TimeBanking by providing presentations, courses, } \\
\text { manuals, guide-books and materials, workshops, conferences, strategic planning, and } \\
\text { mentoring for communities and organizations at grass-roots, professional, academic and } \\
\text { policy levels; } \\
\text { The TimeBanking movement is spreading across the United States and internationally. It } \\
\text { now includes a network of } 200+\text { independent TimeBanks in the United States. } 32+\text { countries } \\
\text { have active TimeBanks. }\end{array}$ \\
\hline TimeBanks & & $\begin{array}{l}\text { AS PER TODAY, AUGUST 3, } 2017 \\
\text { TimeBanks stresses its identity claims in its website, by self-referring itself as: } \\
\text { "Timebanking is a time-based currency that helps to build circles and network of mutual } \\
\text { support. With timebanking, you give one hour of service to another, and receive one time } \\
\text { credit. An hour is always an hour (regardless of the service offered). You can use the credits } \\
\text { in turn to receive services - or you can donate them to others"; } \\
\text { "Timebanks can be local, regional, national or international in scope. They can vary in size } \\
\text { from as few as } 20 \text { people to tens of thousands. Most (but not all) timebanks use } \\
\text { timebanking software, which helps them keep track of member activity". }\end{array}$ \\
\hline
\end{tabular}

\begin{tabular}{|c|c|c|}
\hline $\begin{array}{l}\text { Prototypical } \\
\text { Organization }\end{array}$ & $\begin{array}{c}\text { Architype of SE } \\
\text { activity }\end{array}$ & Milestone Facts \& Events \\
\hline \multirow{4}{*}{$\begin{array}{l}\text { makerspaces } \\
\text { man }\end{array}$} & $\begin{array}{l}\text { Business-to-peer } \\
\text { Non-profit }\end{array}$ & 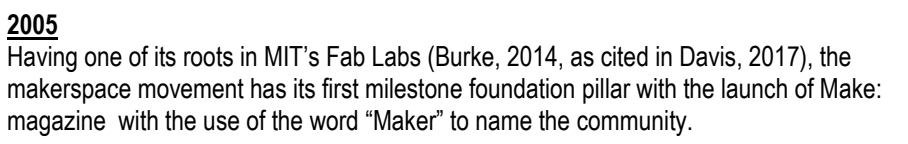 \\
\hline & & $\begin{array}{l}\frac{2006}{\text { A further catalyst for the surge of the maker movement was the Launch of Maker Faires. }} \\
\text { The first was held in } 2006 \text { in the San Francisco Bay Area. }\end{array}$ \\
\hline & & $\begin{array}{l}\frac{2016}{\text { There were nearly } 200 \text { Maker Faire around the world with four of the events drawing at or }} \\
\text { above } 100,000 \text { people in San Mateo, New York, Rome and Shenzhen. }\end{array}$ \\
\hline & & $\begin{array}{l}\text { 2005-2017 } \\
\text { During this period, Make: has been published bi-monthly in print and featuring dozens of } \\
\text { DIY technology projects. }\end{array}$ \\
\hline
\end{tabular}




(continuation of
table 1)

Source: Airbnb, 2017; Zipcar, 2017a; Zipcar, 2017b; Eha, 2013; Kaufman, 2016; TimeBanks, 2017; Make: makerspaces, 2017; Davis, 2017.

Evolution of Legitimacy Granting by Stakeholders, External Actors, Interested Audiences

Scientific Community

Table 2 below presents the results in a concise timeline of the key events related with the evolution of legitimacy granting by the scientific community to four prototypical SE organizations: Airbnb, Zipcar, Timebanks and Make: makerspaces.

Table 2 - Evolution of Legitimacy Granting by Scientific Community

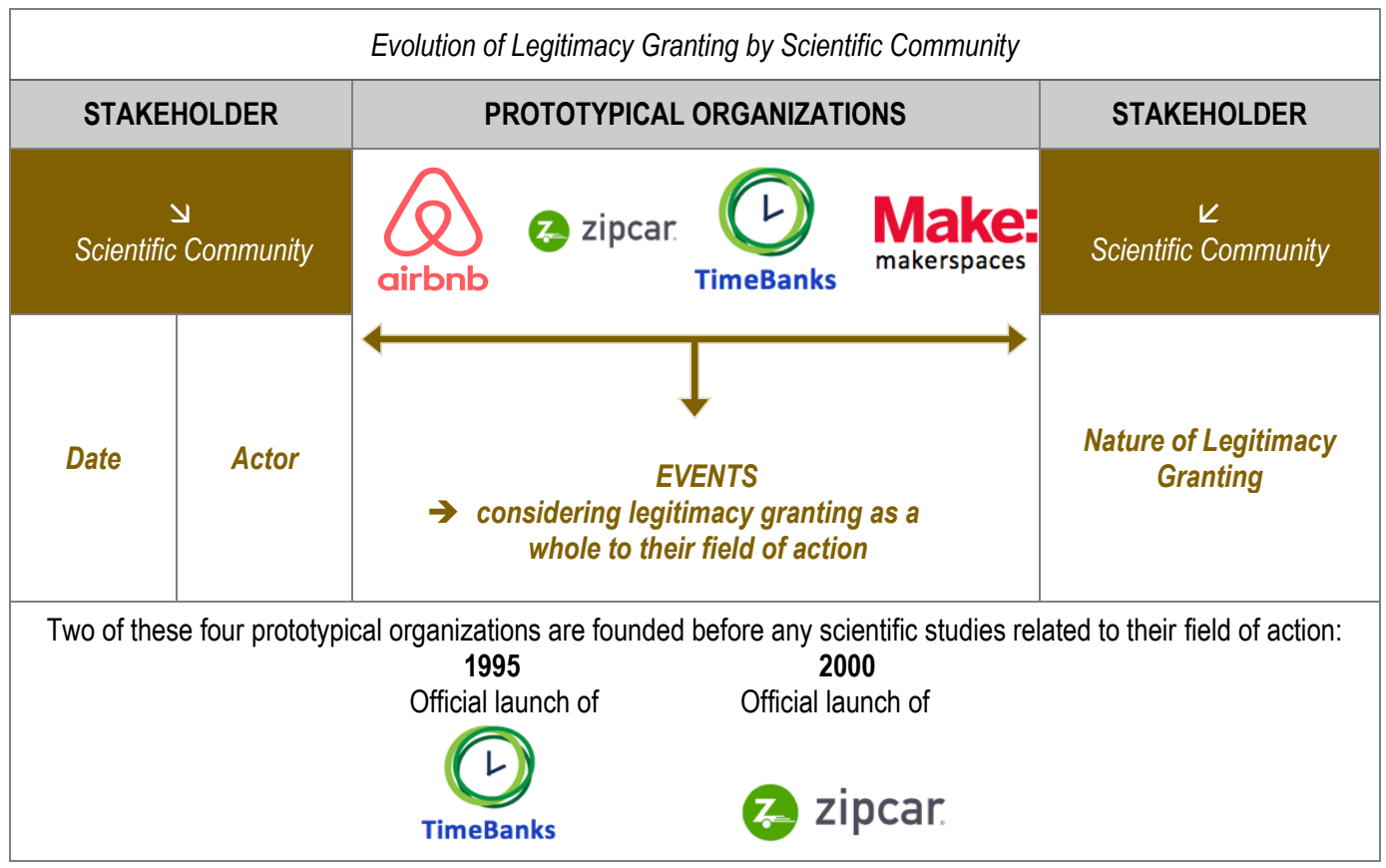




\begin{tabular}{|c|c|c|c|}
\hline \multicolumn{4}{|c|}{ (continuation of table 2) } \\
\hline 2002 & Benkler & $\begin{array}{l}\text { Introduction of the concept "commons-based peer } \\
\text { production". }\end{array}$ & $\begin{array}{l}\text { Very early days of } \\
\text { Cognitive Legitimation. }\end{array}$ \\
\hline \multicolumn{4}{|c|}{$\begin{array}{l}2005 \\
\text { Official launch of }\end{array}$} \\
\hline 2005 & Bauwens & $\begin{array}{l}\text { Publication of an essay "The Political Economy of Peer } \\
\text { Production". }\end{array}$ & $\begin{array}{l}\text { Very early days of } \\
\text { Cognitive Legitimation. }\end{array}$ \\
\hline 2008 & Lessig & Introduction of the term "Sharing Economy". & $\begin{array}{l}\text { Very early days of } \\
\text { Cognitive Legitimation. }\end{array}$ \\
\hline \multicolumn{4}{|c|}{$\begin{array}{l}2008 \\
\text { Official launch of }\end{array}$} \\
\hline 2010 & $\begin{array}{l}\text { Botsman \& } \\
\text { Rogers }\end{array}$ & $\begin{array}{l}\text { Publication of Book "What's mine is yours: The rise of the } \\
\text { Collaborative Consumption". Introduction of the term } \\
\text { "collaborative consumption". }\end{array}$ & $\begin{array}{l}\text { Early days of } \\
\text { Cognitive Legitimation; } \\
\text { Credibility. }\end{array}$ \\
\hline 2012 & $\begin{array}{l}\text { Bardhi \& } \\
\text { Eckhardt }\end{array}$ & $\begin{array}{l}\text { Introduction of the expression: "access-based } \\
\text { consumption". }\end{array}$ & $\begin{array}{l}\text { Early days of } \\
\text { Cognitive Legitimation; } \\
\text { Credibility. }\end{array}$ \\
\hline 2013 & Owyang & Introduction of the concept "Collaborative Economy". & $\begin{array}{l}\text { Cognitive Legitimation; } \\
\text { Credibility. }\end{array}$ \\
\hline 2014 & Belk & $\begin{array}{l}\text { The author criticizes Botsman's \& Rogers' approach by } \\
\text { defining collaborative consumption as "people } \\
\text { coordinating the acquisition and distribution of a resource } \\
\text { for a fee or other compensation". }\end{array}$ & $\begin{array}{l}\text { Cognitive Legitimation; } \\
\text { Credibility. }\end{array}$ \\
\hline
\end{tabular}


(continuation of table 2)

\begin{tabular}{|c|c|c|c|}
\hline $2014 / 2015$ & $\begin{array}{l}\text { Dubois, et } \\
\text { al. (2014); } \\
\text { Schor } \\
(2014, \\
2015) ; \\
\text { Schor \& } \\
\text { Fitzmaurice } \\
\text { (2015); } \\
\text { Schor et al. } \\
\text { (2014) }\end{array}$ & $\begin{array}{l}\text { Contribution in defining the SE. Introduction of the } \\
\text { expression: "connected consumption". }\end{array}$ & $\begin{array}{l}\text { Cognitive Legitimation; } \\
\text { Credibility. }\end{array}$ \\
\hline 2015 & $\begin{array}{l}\text { Frenken et } \\
\text { al.; } \\
\text { Meelen \& } \\
\text { Frenken }\end{array}$ & Further contribution in defining the SE. & $\begin{array}{l}\text { Consolidation of Cognitive } \\
\text { Legitimation; Credibility. }\end{array}$ \\
\hline 2015 & $\begin{array}{l}\text { Hamari et } \\
\text { al. }\end{array}$ & $\begin{array}{l}\text { Introduction of an alternative definition of Collaborative } \\
\text { Consumption: it's "a peer-to-peer-based activity of } \\
\text { obtaining, giving, or sharing the access to goods and } \\
\text { services, coordinated through community-based online } \\
\text { services". }\end{array}$ & $\begin{array}{l}\text { Consolidation of Cognitive } \\
\text { Legitimation; Credibility. }\end{array}$ \\
\hline 2015 & Kim et al. & $\begin{array}{l}\text { Publication of a study "Why people participate in the } \\
\text { Sharing Economy: A Social Exchange Perspective". }\end{array}$ & $\begin{array}{l}\text { Cognitive Legitimation; } \\
\text { Credibility. }\end{array}$ \\
\hline 2016 & $\begin{array}{l}\text { Knote \& } \\
\text { Blohm }\end{array}$ & $\begin{array}{l}\text { Publication of a study "Deconstructing the Sharing } \\
\text { Economy: On the Relevance for IS Research". }\end{array}$ & $\begin{array}{l}\text { Cognitive Legitimation; } \\
\text { Credibility. }\end{array}$ \\
\hline 2016 & Lee et al. & $\begin{array}{l}\text { Publication of "A Study on Factors Influencing Consumers' } \\
\text { Information Needs for Sharing Economy Service". }\end{array}$ & $\begin{array}{l}\text { Cognitive Legitimation; } \\
\text { Credibility. }\end{array}$ \\
\hline 2016 & Cheng & $\begin{array}{l}\text { Publication of "Sharing Economy: A review and agenda } \\
\text { for future research". }\end{array}$ & $\begin{array}{l}\text { Consolidation of Cognitive } \\
\text { Legitimation; Credibility; } \\
\text { Sociopolitical Legitimation } \\
\text { discussion. }\end{array}$ \\
\hline 2016 & $\begin{array}{l}\text { Bonciu \& } \\
\text { Bâlgar }\end{array}$ & $\begin{array}{l}\text { Publication of a study "Sharing Economy as a Contributor } \\
\text { to Sustainable Growth. An EU Perspective". }\end{array}$ & $\begin{array}{c}\text { Consolidation of Cognitive } \\
\text { Legitimation; Credibility; } \\
\text { Sociopolitical Legitimation } \\
\text { discussion. }\end{array}$ \\
\hline
\end{tabular}




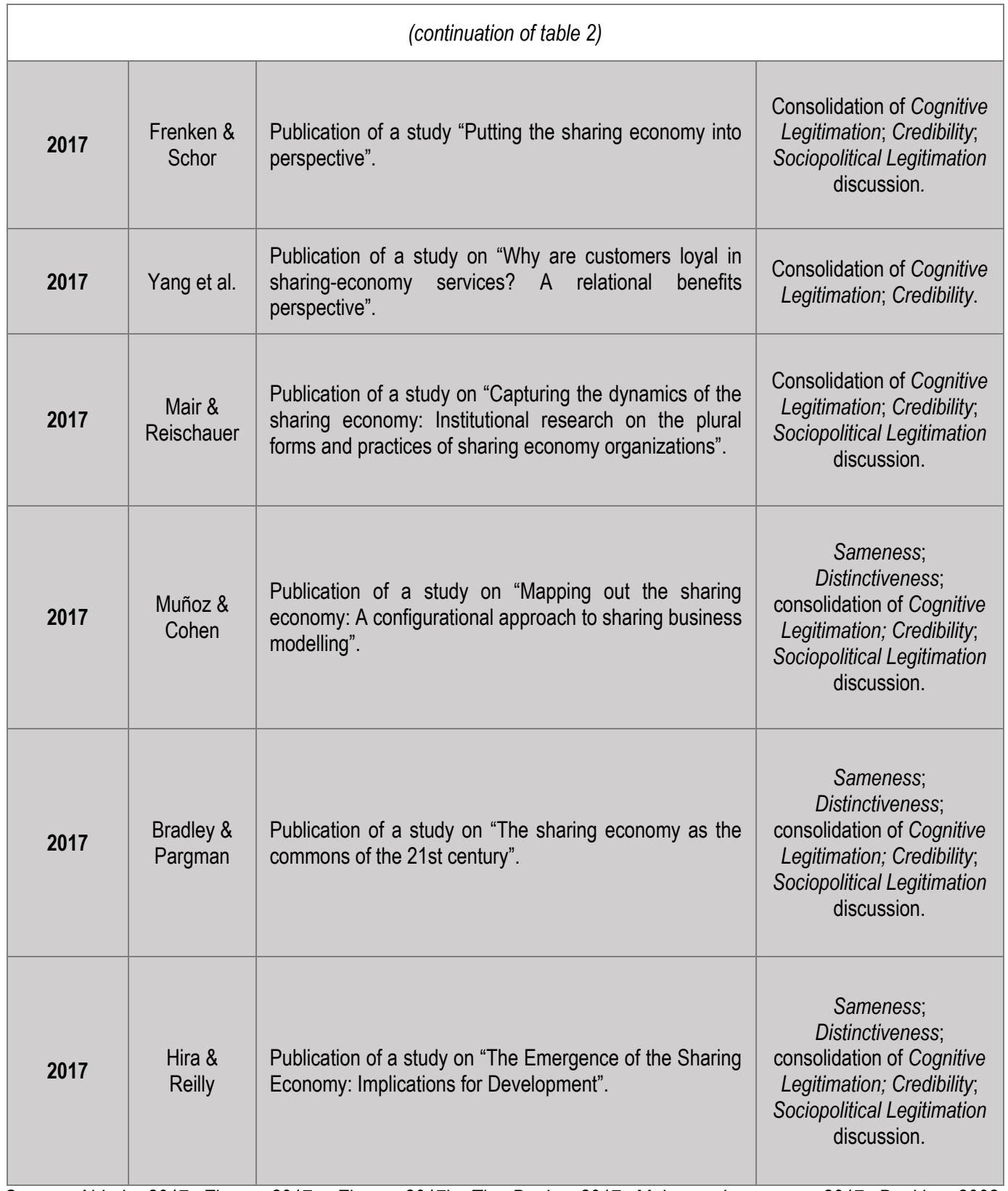

Source: Airbnb, 2017; Zipcar, 2017a; Zipcar, 2017b; TimeBanks, 2017; Make: makerspaces, 2017; Benkler, 2002; Bauwens, 2005; Lessig, 2008; Botsman \& Rogers, 2010; Bardhi \& Eckhardt, 2012; Owyang, 2013; Belk, 2014; Dubois et al., 2014; Schor, 2014; Schor, 2015; Schor \& Fitzmaurice, 2015; Schor et al., 2014; Frenken et al., 2015; Meelen \& Frenken, 2015; Hamari et al., 2015; Kim et al., 2015; Knote \& Blohm, 2016; Lee et al., 2016; Cheng, 2016; Bonciu \& Bâlgar, 2016; Frenken \& Schor, 2017; Yang et al., 2017; Mair \& Reischauer, 2017; Muñoz \& Cohen, 2017; Hira \& Reilly, 2017; Bradley \& Pargman, 2017. 
Investors

Table 3 below presents the results in a concise timeline of the key events related with the evolution of legitimacy granting by investors to four prototypical SE organizations: Airbnb, Zipcar, Timebanks and Make: makerspaces.

Table 3 - Evolution of Legitimacy Granting by Investors

\begin{tabular}{|c|c|c|c|}
\hline \multicolumn{4}{|c|}{ Evolution of Legitimacy Granting by Investors } \\
\hline \multicolumn{2}{|c|}{ STAKEHOLDER } & $\begin{array}{l}\text { PROTOTYPICAL } \\
\text { ORGANIZATIONS }\end{array}$ & STAKEHOLDER \\
\hline \multicolumn{2}{|c|}{$\begin{array}{c}\searrow \\
\text { Investors }\end{array}$} & $\begin{array}{c}\text { EVENTS } \\
\Rightarrow \begin{array}{c}\text { considering individual } \\
\text { legitimacy granting }\end{array}\end{array}$ & $\frac{K}{\text { Investors }}$ \\
\hline Date & Actor & & Nature of Legitimacy Granting \\
\hline $\begin{array}{l}\text { January } \\
2009\end{array}$ & Y Combinator & Investment of $\$ 20$ thousand. & Cognitive Legitimation; Credibility. \\
\hline $\begin{array}{l}\text { April } \\
2009\end{array}$ & $\begin{array}{c}\text { Sequoia Capital } \\
\text { and } \\
\text { Y Ventures }\end{array}$ & Investment of $\$ 600$ thousand. & Cognitive Legitimation; Credibility. \\
\hline $\begin{array}{l}\text { November } \\
2010\end{array}$ & $\begin{array}{c}\text { Greylock } \\
\text { Partners; } \\
\text { Keith Rabois; } \\
\text { Y Ventures; SV } \\
\text { Angel; Elad Gil; } \\
\text { Jeremy } \\
\text { Stoppelman; } \\
\text { Ashton Kutcher; } \\
\text { Sequoia Capital }\end{array}$ & Investment of $\$ 7.2$ million. & Cognitive Legitimation; Credibility. \\
\hline $\begin{array}{l}\text { July } \\
2011\end{array}$ & $\begin{array}{l}\text { CrunchFund; } \\
\text { Ashton Kutcher; } \\
\text { Jeff Bezos; } \\
\text { General Catalyst; } \\
\text { DST Global; } \\
\text { Andreessen } \\
\text { Horowitz; } \\
\text { Oliver Jung; } \\
\text { Sequoia Capital }\end{array}$ & Investment of $\$ 112$ million. & Cognitive Legitimation; Credibility. \\
\hline $\begin{array}{l}\text { October } \\
2013\end{array}$ & $\begin{array}{l}\text { Ashton Kutcher; } \\
\text { CrunchFund; } \\
\text { Founders Fund; } \\
\text { Sequoia Capital; } \\
\text { Airbnb }\end{array}$ & Investment of $\$ 200$ million. & Cognitive Legitimation; Credibility. \\
\hline
\end{tabular}




\begin{tabular}{|c|c|c|c|}
\hline \multicolumn{4}{|c|}{ (continuation of table 3) } \\
\hline $\begin{array}{l}\text { April } \\
2014\end{array}$ & $\begin{array}{l}\text { Dragoneer } \\
\text { Investment } \\
\text { Group; } \\
\text { T. Rowe Price; } \\
\text { TPG Growth; } \\
\text { Sherpa Capital; } \\
\text { Sequoia Capital; } \\
\text { Andreessen } \\
\text { Horowitz }\end{array}$ & Investment of $\$ 475$ million. & Cognitive Legitimation; Credibility. \\
\hline $\begin{array}{l}\text { June } \\
2015\end{array}$ & $\begin{array}{l}\text { Groupe Arnault; } \\
\text { Horizons } \\
\text { Ventures; } \\
\text { Hillhouse Capital } \\
\text { Group; General } \\
\text { Atlantic; Tiger } \\
\text { Global } \\
\text { Management; } \\
\text { Temasek } \\
\text { Holdings; Kleiner } \\
\text { Perkins Caufield } \\
\text { \& Byers; GGV } \\
\text { Capital; China } \\
\text { Broadband } \\
\text { Capital; } \\
\text { Wellington } \\
\text { Management; } \\
\text { Baillie Gifford; } \\
\text { T. Rowe Price; } \\
\text { Fidelity } \\
\text { Investments; } \\
\text { Sequoia Capital }\end{array}$ & Investment of $\$ 1.5$ billion. & Cognitive Legitimation; Credibility. \\
\hline $\begin{array}{l}\text { November } \\
2015\end{array}$ & FirstMark & Investment of $\$ 100$ million. & Cognitive Legitimation; Credibility. \\
\hline $\begin{array}{l}\text { June } \\
2016\end{array}$ & $\begin{array}{l}\text { JP Morgan Chase } \\
\text { \& Co.; Citigroup; } \\
\text { Morgan Stanley; } \\
\text { Brand Capital }\end{array}$ & Investment of $\$ 1$ billion. & Cognitive Legitimation; Credibility. \\
\hline $\begin{array}{l}\text { September } \\
2016\end{array}$ & $\begin{array}{l}\text { Altimeter Capital; } \\
\text { Glade Brook } \\
\text { Capital Partners; } \\
\text { Geodesic Capital; } \\
\text { TCV; CapitalG }\end{array}$ & Investment of $\$ 555.46$ million. & Cognitive Legitimation; Credibility. \\
\hline $\begin{array}{l}\text { March } \\
2017\end{array}$ & $\begin{array}{l}\text { Jeff Jordan; } \\
\text { Alfred Lin; } \\
\text { TCV; CapitalG }\end{array}$ & Investment of $\$ 447.8$ million. & Cognitive Legitimation; Credibility. \\
\hline
\end{tabular}




\begin{tabular}{|c|c|c|c|}
\hline \multicolumn{4}{|c|}{ (continuation of table 3) } \\
\hline Date & Actor & $\begin{array}{l}\text { (2) } \\
z=\text { zipcar. }\end{array}$ & Nature of Legitimacy Granting \\
\hline $\begin{array}{l}\text { December } \\
2002\end{array}$ & $\begin{array}{l}\text { Name of } \\
\text { entity(ies) not } \\
\text { available }\end{array}$ & $\begin{array}{l}\$ 4.7 \text { million raised in a venture } \\
\text { round (Series B). }\end{array}$ & Cognitive Legitimation; Credibility. \\
\hline $\begin{array}{l}\text { November } \\
2003\end{array}$ & $\begin{array}{l}\text { Boston } \\
\text { Community } \\
\text { Capital }\end{array}$ & Investment of $\$ 2$ million. & Cognitive Legitimation; Credibility. \\
\hline $\begin{array}{l}\text { January } \\
2005\end{array}$ & Benchmark & Investment of $\$ 10$ million. & Cognitive Legitimation; Credibility. \\
\hline $\begin{array}{c}\text { November } \\
2006\end{array}$ & $\begin{array}{c}\text { Greylock } \\
\text { Partners; } \\
\text { Benchmark; } \\
\text { Globespan } \\
\text { Capital Partners }\end{array}$ & Investment of $\$ 25$ million. & Cognitive Legitimation; Credibility. \\
\hline $\begin{array}{c}\text { November } \\
2007\end{array}$ & $\begin{array}{l}\text { Boston } \\
\text { Community } \\
\text { Capital; } \\
\text { Benchmark }\end{array}$ & Investment of $\$ 45$ million. & Cognitive Legitimation; Credibility. \\
\hline $\begin{array}{l}\text { December } \\
2010\end{array}$ & $\begin{array}{l}\text { Pinnacle } \\
\text { Ventures; } \\
\text { Meritech Capital } \\
\text { Partners }\end{array}$ & Investment of $\$ 21$ million. & Cognitive Legitimation; Credibility. \\
\hline $\begin{array}{l}\text { January } \\
2013\end{array}$ & $\begin{array}{l}\text { Avis Budget } \\
\text { Group }\end{array}$ & $\begin{array}{l}\text { Buys Zipcar for } \$ 500 \text { million } \\
\text { (Zipcar, though, will operate as } \\
\text { an Avis subsidiary, retain its } \\
\text { CEO and chief operating } \\
\text { officer) }\end{array}$ & Cognitive Legitimation; Credibility. \\
\hline Date & Actor & TimeBanks & Nature of Legitimacy Granting \\
\hline \multicolumn{4}{|c|}{$\begin{array}{c}\text { NO INVESTORS } \\
\text { (Non-Profit prototypical organization) }\end{array}$} \\
\hline Date & Actor & $\frac{4}{\text { makerspaces }}$ & Nature of Legitimacy Granting \\
\hline \multicolumn{4}{|c|}{$\begin{array}{c}\text { NO INVESTORS } \\
\text { (Non-Profit prototypical organization) }\end{array}$} \\
\hline
\end{tabular}

Source: Crunchbase, 2017a; Crunchbase, 2017b. 


\section{Customers}

Table 4 below presents the results in a concise timeline of the key events related with the evolution of legitimacy granting by customers to four prototypical SE organizations: Airbnb, Zipcar, Timebanks and Make: makerspaces.

Table 4 - Evolution of Legitimacy Granting by Customers

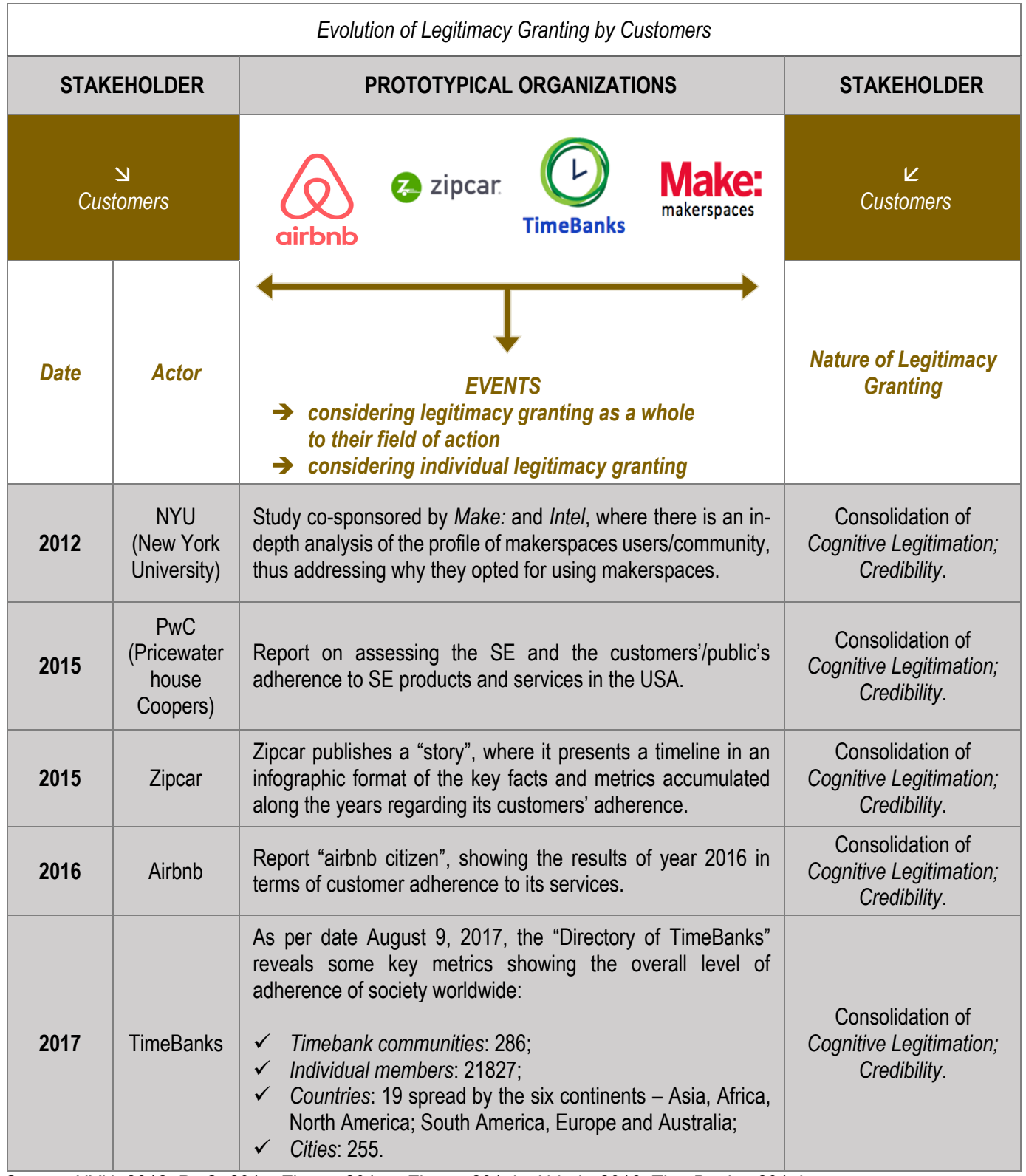

Source: NYU, 2012; PwC, 2015; Zipcar, 2017a; Zipcar, 2017b; Airbnb, 2016; TimeBanks, 2017b. 
Media

Table 5 below presents the results in a concise timeline of the key events related with the evolution of legitimacy granting by the media to four prototypical SE organizations: Airbnb, Zipcar, Timebanks and Make: makerspaces.

Table 5 - Evolution of Legitimacy Granting by the Media

\begin{tabular}{|c|c|c|c|}
\hline \multicolumn{4}{|c|}{ Evolution of Legitimacy Granting by Media } \\
\hline \multicolumn{2}{|c|}{ STAKEHOLDER } & PROTOTYPICAL ORGANIZATIONS & STAKEHOLDER \\
\hline \multicolumn{2}{|c|}{$\stackrel{y}{\text { Media }}$} & \multirow[b]{2}{*}{\begin{aligned} & \multicolumn{1}{c}{ EVENTS } \\
&$\rightarrow$ considering legitimacy granting as a whole \\
& to their field of action \end{aligned}} & $\underset{M e d i a}{K}$ \\
\hline Date & Actor & & $\begin{array}{l}\text { Nature of Legitimacy } \\
\text { Granting }\end{array}$ \\
\hline \multicolumn{4}{|c|}{$\begin{array}{c}\text { PRESS } \\
\text { (newspapers and magazines) }\end{array}$} \\
\hline 2015 & $\begin{array}{l}\text { Fortune } \\
\text { (Magazine) }\end{array}$ & $\begin{array}{l}\text { Alternative terms to SE are brought forward: Gig } \\
\text { Economy, On-Demand Economy and Rental Economy. }\end{array}$ & $\begin{array}{l}\text { Cognitive Legitimation; } \\
\text { Credibility. }\end{array}$ \\
\hline 2015 & $\begin{array}{l}\text { The New } \\
\text { York Times } \\
\text { (Newspaper) }\end{array}$ & $\begin{array}{l}\text { Article on the malefic effects of Airbnb renting for a local } \\
\text { and quite neighborhood in Austin, Texas, USA. }\end{array}$ & $\begin{array}{l}\text { Cognitive Legitimation; } \\
\text { Credibility discussion; } \\
\text { Sociopolitical Legitimation } \\
\text { discussion. }\end{array}$ \\
\hline 2015 & $\begin{array}{l}\text { WSJ } \\
\text { (The Wall } \\
\text { Street } \\
\text { Journal) }\end{array}$ & $\begin{array}{l}\text { Article on the effect of Airbnb listings on the } \\
\text { accommodation sector, particularly on "Hotel's Power", } \\
\text { during Pope's US visit. Main conclusions of the article. }\end{array}$ & $\begin{array}{l}\text { Consolidation of Cognitive } \\
\text { Legitimation; Credibility. }\end{array}$ \\
\hline 2016 & $\begin{array}{l}\text { FT } \\
\text { (Financial } \\
\text { Times } \\
\text { Newspaper) }\end{array}$ & $\begin{array}{l}\text { Article about the Sharing Economy, arguing that } \\
\text { "regulators should not rush to curb Uber and Airbnb". }\end{array}$ & $\begin{array}{l}\text { Cognitive Legitimation; } \\
\text { Credibility; Sociopolitical } \\
\text { Legitimation discussion. }\end{array}$ \\
\hline
\end{tabular}




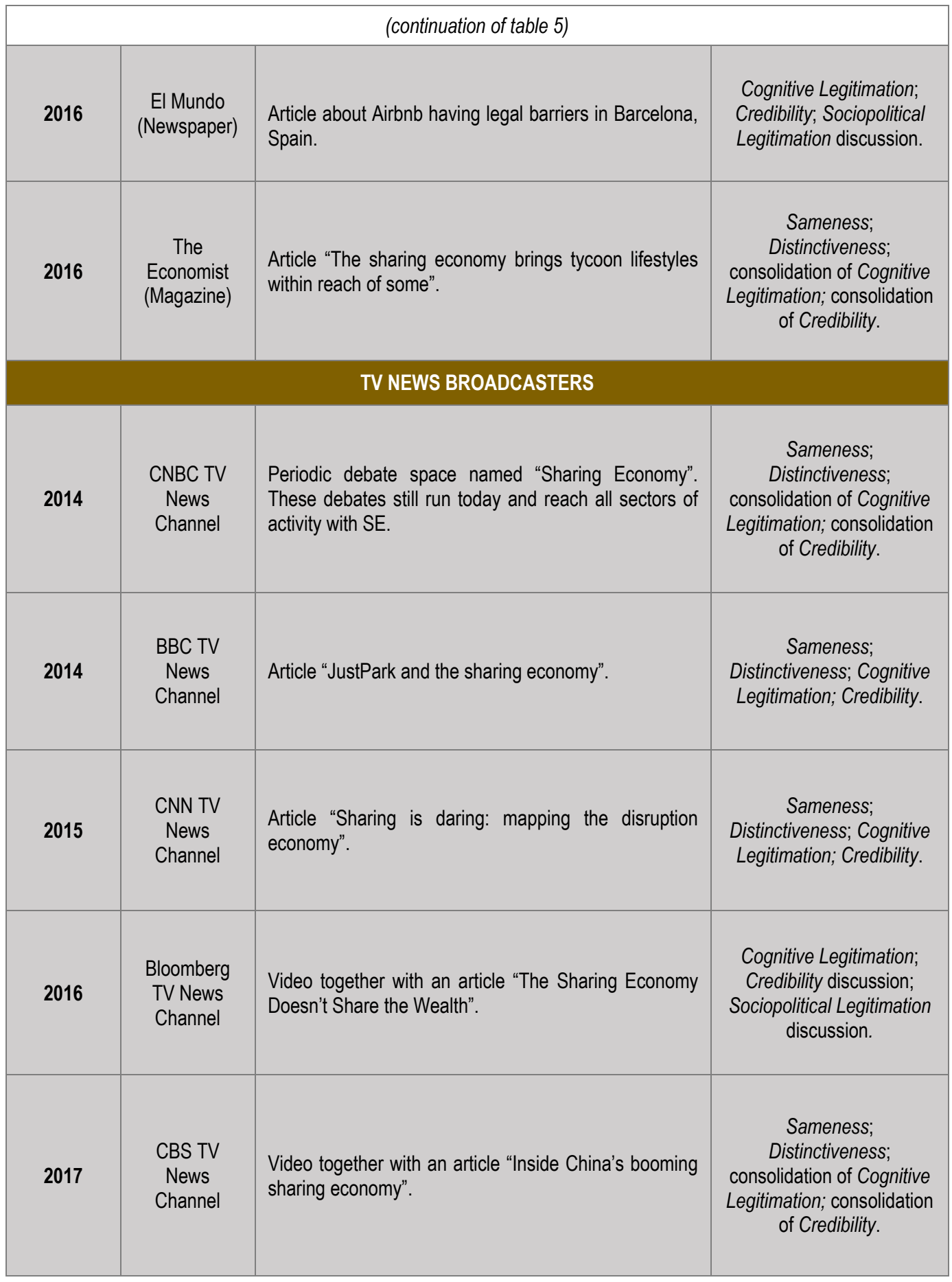




\section{(continuation of table 5)}

\section{SOCIAL NETWORKS}

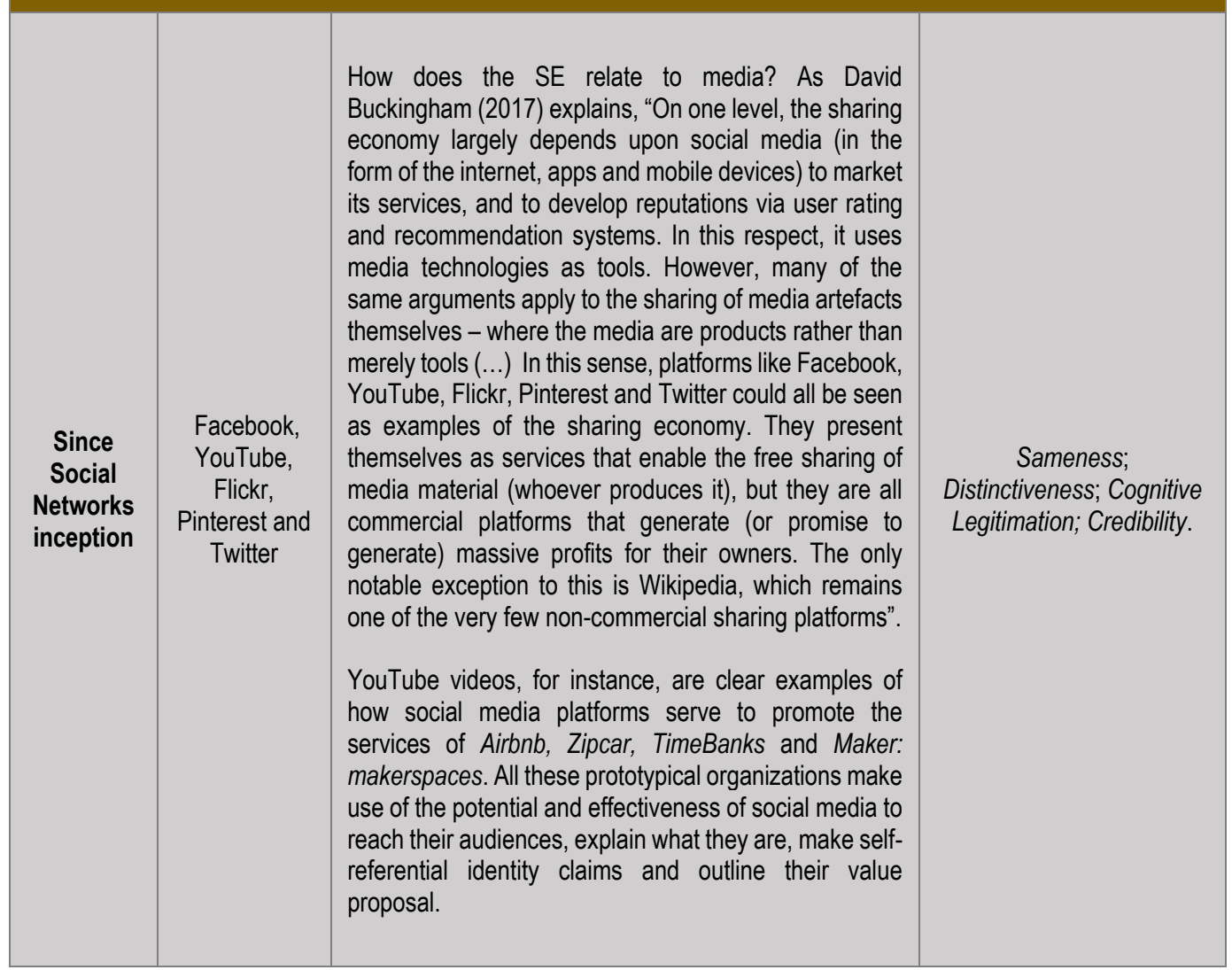

Source: Fortune, 2015; The New York Times, 2015; WSJ, 2015; FT, 2016a; El mundo, 2016; The Economist, 2016; CNBC, 2014; BBC News, 2014; CNN, 2015; Bloomberg, 2016; CBS, 2017; Buckingham, 2017. 


\section{Other Analysts}

Table 6 below presents the results in a concise timeline of the key events related with the evolution of legitimacy granting by other analysts to four prototypical SE organizations: Airbnb, Zipcar, Timebanks and Make: makerspaces.

Table 6 - Evolution of Legitimacy Granting by Other Analysts

\begin{tabular}{|c|c|c|c|}
\hline \multicolumn{4}{|c|}{ Evolution of Legitimacy Granting by Other Analysts } \\
\hline \multicolumn{2}{|c|}{ STAKEHOLDER } & PROTOTYPICAL ORGANIZATIONS & STAKEHOLDER \\
\hline \multicolumn{2}{|c|}{$\begin{array}{c}\stackrel{\searrow}{ } \\
\text { Other Analysts }\end{array}$} & z zipcar (レ) Make: & $\begin{array}{c}K \\
\text { Other Analysts }\end{array}$ \\
\hline Date & Actor & $\begin{array}{c}\quad \text { EVENTS } \\
\rightarrow \text { considering legitimacy granting as a whole } \\
\text { to their field of action } \\
\rightarrow \text { considering individual legitimacy granting }\end{array}$ & $\begin{array}{c}\text { Nature of Legitimacy } \\
\text { Granting }\end{array}$ \\
\hline 2010 & Gansky & Book "The Mesh". Introduction of the term "Mesh". & $\begin{array}{c}\text { Consolidation of } \\
\text { Cognitive Legitimation; } \\
\text { Credibility. }\end{array}$ \\
\hline 2015 & OECD & The Organization attempts to define the SE. & $\begin{array}{c}\text { Consolidation of } \\
\text { Cognitive Legitimation; } \\
\text { Credibility. }\end{array}$ \\
\hline 2015 & $\begin{array}{c}\text { PwC } \\
\text { (Pricewaterh } \\
\text { ouse } \\
\text { Coopers) }\end{array}$ & Report on assessing the SE. & $\begin{array}{c}\text { Consolidation of } \\
\text { Cognitive Legitimation; } \\
\text { Credibility. }\end{array}$ \\
\hline 2016 & $\begin{array}{c}\text { ESA } \\
\text { (Economics } \\
\text { and Statistics } \\
\text { Administratio } \\
\mathrm{n} \text { of the U.S. } \\
\text { Commerce } \\
\text { Department) }\end{array}$ & $\begin{array}{l}\text { Report attempting to define and map out the contours of } \\
\text { the SE. }\end{array}$ & $\begin{array}{c}\text { Consolidation of } \\
\text { Cognitive Legitimation; } \\
\text { Credibility. }\end{array}$ \\
\hline 2016 & Sundararajan & $\begin{array}{l}\text { Book "The Sharing Economy: the end of employment and } \\
\text { the rise of crowd-based capitalism". }\end{array}$ & $\begin{array}{c}\text { Consolidation of } \\
\text { Cognitive Legitimation; } \\
\text { Credibility. }\end{array}$ \\
\hline
\end{tabular}




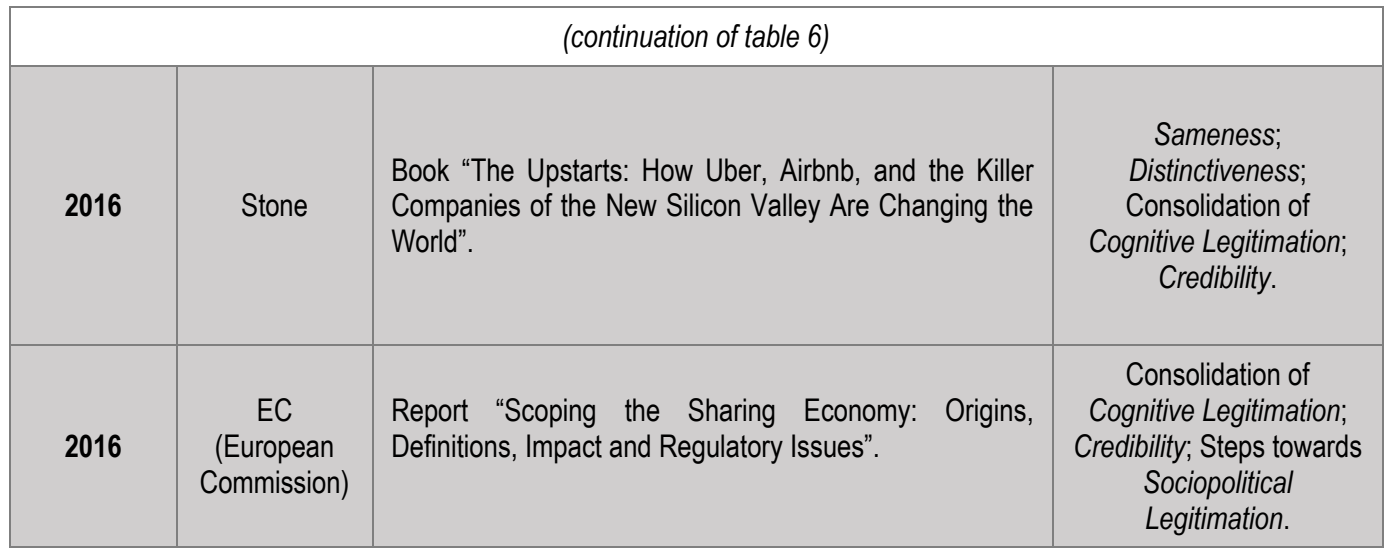

Source: Gansky, 2010; OECD, 2015a, OECD, 2015b; PwC, 2015; ESA, 2016; Sundararajan, 2016; Stone, 2016; EC, 20016.

\section{Other Interested Audiences}

Table 7 below presents the results in a concise timeline of the key events related with the evolution of legitimacy granting by other interested audiences to four prototypical SE organizations: Airbnb, Zipcar, Timebanks and Make: makerspaces.

Table 7 - Evolution of Legitimacy Granting by Other Interested Audiences

\begin{tabular}{|c|c|c|c|}
\hline \multicolumn{4}{|c|}{ Evolution of Legitimacy Granting by Other Interested Audiences } \\
\hline \multicolumn{2}{|c|}{ STAKEHOLDER } & PROTOTYPICAL ORGANIZATIONS & STAKEHOLDER \\
\hline \multicolumn{2}{|c|}{$\begin{array}{l}У \\
\text { Other Interested } \\
\text { Audiences }\end{array}$} & z zipcar (ᄂ) & $\begin{array}{l}\mathbf{k} \\
\text { Other Interested } \\
\text { Audiences }\end{array}$ \\
\hline Date & Actor & \begin{aligned} & \multicolumn{1}{c}{ EVENTS } \\
$\rightarrow &$ considering legitimacy granting as a whole \\
& to their field of action \\
$\rightarrow &$ considering individual legitimacy granting \end{aligned} & $\begin{array}{l}\text { Nature of Legitimacy } \\
\text { Granting }\end{array}$ \\
\hline 2013 & $\begin{array}{l}\text { Switzer } \\
\text { Foundation } \\
\text { (Boston, } \\
\text { USA) }\end{array}$ & $\begin{array}{l}\text { Conference: "Sharing Economy Conference: Boston } \\
\text { with Julia Ledewitz". }\end{array}$ & $\begin{array}{l}\text { Early days of Cognitive } \\
\text { Legitimation; Credibility }\end{array}$ \\
\hline 2015 & $\begin{array}{c}\text { Breakers } \\
\text { Makers } \\
\text { (London, UK) }\end{array}$ & $\begin{array}{l}\text { Conference: "The Sharing Economy \& On Demand } \\
\text { Conference". }\end{array}$ & $\begin{array}{l}\text { Cognitive Legitimation; } \\
\text { Credibility. }\end{array}$ \\
\hline 2015 & $\begin{array}{c}\text { Oxford } \\
\text { Dictionary }\end{array}$ & $\begin{array}{l}\text { The terms "Sharing Economy" (SE) and "Ride-Share" } \\
\text { (RS) are added to Oxford Dictionary. }\end{array}$ & $\begin{array}{l}\text { Reinforcement of } \\
\text { Cognitive Legitimation } \\
\text { and Credibility. }\end{array}$ \\
\hline
\end{tabular}




\begin{tabular}{|c|c|c|c|}
\hline \multicolumn{4}{|c|}{ (continuation of table 7) } \\
\hline 2015 & $\begin{array}{l}\text { U.S. House } \\
\text { (Washington } \\
\text { DC, USA) }\end{array}$ & "The Congressional Sharing Economy Caucus". & $\begin{array}{l}\text { Consolidation of } \\
\text { Cognitive Legitimation; } \\
\text { Credibility. }\end{array}$ \\
\hline 2015 & $\begin{array}{l}\text { FCT } \\
\text { (Federal } \\
\text { Trade } \\
\text { Commission) }\end{array}$ & $\begin{array}{l}\text { Public Workshop to Examine Competition, Consumer } \\
\text { Protection and Economic Issues Raised by the Sharing } \\
\text { Economy. }\end{array}$ & $\begin{array}{l}\text { Consolidation of } \\
\text { Cognitive Legitimation; } \\
\text { Credibility. }\end{array}$ \\
\hline 2015 & $\begin{array}{l}\text { Utrecht } \\
\text { University } \\
\text { (Utrecht, } \\
\text { Netherlands) }\end{array}$ & $\begin{array}{l}\text { Workshop: "First International Workshop on the } \\
\text { Sharing Economy". }\end{array}$ & $\begin{array}{l}\text { Consolidation of } \\
\text { Cognitive Legitimation; } \\
\text { Credibility. }\end{array}$ \\
\hline 2016 & $\begin{array}{l}\text { Milken } \\
\text { Institute } \\
\text { (Santa } \\
\text { Monica, LA, } \\
\text { USA) }\end{array}$ & $\begin{array}{l}\text { Conference: "Is the Sharing Economy the New } \\
\text { Normal?". }\end{array}$ & $\begin{array}{l}\text { Consolidation of } \\
\text { Cognitive Legitimation; } \\
\text { Credibility. }\end{array}$ \\
\hline 2016 & $\begin{array}{l}\text { ESCP } \\
\text { Europe } \\
\text { (Paris, } \\
\text { France) }\end{array}$ & $\begin{array}{l}\text { Workshop: "Second International Workshop on the } \\
\text { Sharing Economy". }\end{array}$ & $\begin{array}{l}\text { Consolidation of } \\
\text { Cognitive Legitimation; } \\
\text { Credibility. }\end{array}$ \\
\hline 2016 & $\begin{array}{l}\text { Maddox } \\
\text { Events } \\
\text { (London, UK) }\end{array}$ & $\begin{array}{l}\text { Conference: "The Sharing Economy Conference } \\
\text { 2016". }\end{array}$ & $\begin{array}{l}\text { Consolidation of } \\
\text { Cognitive Legitimation; } \\
\text { Credibility. }\end{array}$ \\
\hline 2016 & $\begin{array}{c}\text { University of } \\
\text { Southampton } \\
\text { (Southampto } \\
\text { n, UK) }\end{array}$ & $\begin{array}{l}\text { Workshop: "Third International Workshop on the } \\
\text { Sharing Economy". }\end{array}$ & $\begin{array}{l}\text { Consolidation of } \\
\text { Cognitive Legitimation; } \\
\text { Credibility. }\end{array}$ \\
\hline 2016 & $\begin{array}{l}\text { Financial } \\
\text { Times } \\
\text { (London, UK) }\end{array}$ & $\begin{array}{l}\text { Summit: "FT Sharing Economy Summit Europe } 2016 \text { - } \\
\text { Achieving stability among growing regulation". }\end{array}$ & $\begin{array}{c}\text { Consolidation of } \\
\text { Cognitive Legitimation; } \\
\text { Credibility; Steps towards } \\
\text { Sociopolitical } \\
\text { Legitimation. }\end{array}$ \\
\hline 2016 & $\begin{array}{l}\text { Humboldt- } \\
\text { Universität zu } \\
\text { Berlin } \\
\text { (Berlin, } \\
\text { Germany) }\end{array}$ & $\begin{array}{l}\text { Conference: "7th International Conference on } \\
\text { Corporate Sustainability and Responsibility - CSR In } \\
\text { an Age of Digitization". One of the tracks was about the } \\
\text { "Sharing Economy". }\end{array}$ & $\begin{array}{c}\text { Consolidation of } \\
\text { Cognitive Legitimation; } \\
\text { Credibility; Steps towards } \\
\text { Sociopolitical } \\
\text { Legitimation. }\end{array}$ \\
\hline 2016 & $\begin{array}{l}\text { Ryerson } \\
\text { University } \\
\text { (Toronto, } \\
\text { Canada) }\end{array}$ & $\begin{array}{l}\text { Conference: "The Sharing Economy and the Future of } \\
\text { Work". }\end{array}$ & $\begin{array}{l}\text { Consolidation of } \\
\text { Cognitive Legitimation; } \\
\text { Credibility; Steps towards } \\
\text { Sociopolitical } \\
\text { Legitimation. }\end{array}$ \\
\hline 2017 & $\begin{array}{l}\text { Shidler } \\
\text { College of } \\
\text { Business - } \\
\text { University of } \\
\text { Hawaii } \\
\text { (Mãnoa, } \\
\text { Hawaii) }\end{array}$ & $\begin{array}{l}\text { Conference: "50th Hawaiian International Conference } \\
\text { on System Sciences (HICSS)". One of the tracks was } \\
\text { about the "Sharing Economy". }\end{array}$ & $\begin{array}{l}\text { Consolidation of } \\
\text { Cognitive Legitimation; } \\
\text { Credibility. }\end{array}$ \\
\hline
\end{tabular}




\begin{tabular}{|c|c|c|c|}
\hline \multicolumn{4}{|c|}{ (continuation of table 7) } \\
\hline 2017 & $\begin{array}{l}\text { Lund } \\
\text { University } \\
\text { (Lund, } \\
\text { Sweden) }\end{array}$ & $\begin{array}{l}\text { Workshop: "Fourth International Workshop on the } \\
\text { Sharing Economy". }\end{array}$ & $\begin{array}{l}\text { Consolidation of } \\
\text { Cognitive Legitimation; } \\
\text { Credibility. }\end{array}$ \\
\hline 2017 & $\begin{array}{l}\text { Bizz Grid } \\
\text { (Stockholm, } \\
\text { Sweden) }\end{array}$ & $\begin{array}{l}\text { Conference: "Sharing Economy and Earnings on } \\
\text { Demand". }\end{array}$ & $\begin{array}{l}\text { Consolidation of } \\
\text { Cognitive Legitimation; } \\
\text { Credibility. }\end{array}$ \\
\hline 2017 & $\begin{array}{c}\begin{array}{c}\text { Universidade } \\
\text { do Algarve } \\
\text { (in }\end{array} \\
\text { collaboration } \\
\text { with two } \\
\text { other partner } \\
\text { institutions: } \\
\text { The } \\
\text { University of } \\
\text { Applied } \\
\text { Sciences, } \\
\text { Pforzheim, } \\
\text { Germany; } \\
\text { Autónoma } \\
\text { University, } \\
\text { Madrid, } \\
\text { Spain } \\
\text { (Faro, } \\
\text { Portugal) }\end{array}$ & $\begin{array}{l}\text { Conference: "Sharing Economy - Collaborative } \\
\text { Consumption: Current trends and visions in key } \\
\text { economic areas for Germany and Southern Europe". }\end{array}$ & $\begin{array}{l}\text { Consolidation of } \\
\text { Cognitive Legitimation; } \\
\text { Credibility. }\end{array}$ \\
\hline 2017 & $\begin{array}{l}\text { ATINER - } \\
\text { Athens } \\
\text { Institute for } \\
\text { Education } \\
\text { and } \\
\text { Research } \\
\text { (Athens, } \\
\text { Greece) }\end{array}$ & $\begin{array}{l}\text { Conference: "A Panel on The Sharing Economy as part } \\
\text { of the 4th Annual International Conference on Social } \\
\text { Sciences". }\end{array}$ & $\begin{array}{l}\text { Consolidation of } \\
\text { Cognitive Legitimation; } \\
\text { Credibility. }\end{array}$ \\
\hline
\end{tabular}

Source: Switzer Foundation, 2013; Breakers Makers, 2015; Liftshare, 2015; U.S. House, 2015; FCT, 2015a; FCT, 2015b; FCT, 2015c; Utrecht University, 2015; Milken Institute, 2016; ESCP Europe, 2016; Maddox Events, 2016; University of Southampton, 2016; FT, 2016b; Humboldt-Universität zu Berlin, 2016; Ryerson University, 2016; Shidler College of Business - University of Hawaii, 2017; Lund University, 2017; Bizz Grid, 2017; Universidade do Algarve, 2017; ATINER, 2017. 


\section{Discussion}

From a perspective of the evolution of the identity claims (self-referential) our findings reveal that none of the four prototypical SE organizations identify themselves as belonging to a category named "sharing economy". However, all them present a progressive sustainable evolution in their identity claims with significant milestone events and facts overtime towards their consolidation in the market place. Observing the timeline evolution, we can see how far has each of the organizations evolved. Comparing the two temporal extremes of the timeline - one dated in the inception and another dated August 2017 - of each of them, we may notice how much they have elaborated, gained density and, consequently, got scale dimension along the years.

From a perspective of the evolution of legitimacy granting by stakeholders, and taking into consideration the studies of category creation - (i) Glynn \& Navis, 2013; (ii) Durand \& Paolella, 2013; (iii) Kennedy \& Fiss, 2013; (iv) Kennedy et al., 2010; (v) Lounsbury \& Rao, 2004; (vi) Wry et al., 2014; (vii) Navis \& Glynn, 2010; (viii) Tripsas, 2009; and (ix) Zuckerman, 1999, our findings respectively show that:

SE is still connoted with great uncertainties, category legitimation and, yes, there currently is an increasingly pressure from audiences, specially from Scholars and Governmental officials, in finding a legitimate and disciplined fit in societal categories. SE is acting as a general ambiguous category enabling divergence in identities and business models;

In the exercise of constructing a categorization meaning to SE, yes, one should consider a process that goes beyond a mere rigid, constraint, straitjacket categorical model. That is, SE seems to be contoured by (a) a causal dimension - i.e. since Airbnb uses web 2.0 whose purpose is to enable the sharing (in exchange of money) of rooms between a community, then its interested audiences may extrapolate that it is inserted within the SE category ("cognitive test of congruence") and (b) goal dimension - it generates ad hoc categories (goal-derived categories) - i.e. since Airbnb was created to serve as an appealing alternative, in terms of price, social experience, easiness in accessing, etc., to Hotel Reservations ("goal satisfying calculus"), then its interested audiences tend to legitimate it because it meets their goal satisfying calculus in having access to a less expensive service, more exciting social experience, less complicated reservation experience and an overall enhancement in comfort;

Yes, SE seems to be contoured by the two dimensions described by Kennedy and Fiss (2013): (a) - i.e. There is an "occasion and motivation" dimension for invoking Airbnb as a category. It seems to be a nascent and ad hoc category of "Accommodation", as it facilitates a specific goal (audiences seek access to a less expensive service, more exciting social experience, less complicated reservation experience and an overall enhancement in comfort comparing to Hotel Reservations, for example); and (b) sure the emergence of Airbnb as a new ad hoc category implies a direct effect of preestablished ontologies, due to the simple fact that anything that is nascent and new will force the understanding (its true meaning) of how it will fit within pre-existent conformities and it will re-shape the ontological knowledge on the "accommodation" sector. Thus, the role of SE seems to be as a straitjacket in the definition of organizational identity, and types of business models within it;

Yes, there seems to be a "category currency" dimension associated with the construction of SE as a presumably "alternative" category. Explaining: if one applies the example of Zipcar in Kennedy et al.'s (2010) model of Category Meaning Construction and its 8 ways how category meaning can change, one would elaborate: the Focal Category (or reference category) would be "Taxi transportation", whereas the Alternative for Consideration would be "Zipcar transportation". Moreover, in evaluating the conformity of the latter one (in other words, how would one label it in the context of taxi transportation), one should consider the 8-hypothesis brought forward by Kennedy et al: 1) Should one re-define what "taxi transportation" is?, 2) Should one, instead, derive that there are two distinct services (Taxi and Zipcar), a subdivision, although belonging to the same focal category?, 3) Should one consider that none of these hypothesis is true and that Zipcar represents a subtraction of Taxi (in other words, is Zipcar an ad hoc category of Taxi?), 4) Should one validate that Zipcar is part of the Taxi Focal Category (subsumption)?, 5) Or is Zipcar a substitute of Taxi?, 6) Further, are Zipcar and Taxi a part of a much larger category - "Transportation" -, which allows one to recombine them into a broader categorization?, 7) Even further, is Zipcar inserted in a conglomerate that is formed by several ad hoc categories (ex: transportation in general: Taxi, Zipcar, BUS, Train, Car, Bicycle, Airplane and Boat transportation)?, 8) Or is Zipcar such a disruptive change that makes the market to re-organize itself and invert the logics of the transportation sector? Should, for example, Zipcar become the beacon, the main reference (the rising currency) of the transportation market and incorporate the rest into ad hoc categories (declining currencies) of itself? In other words, all existing "transportation" means should be 
reconsidered and given a radical change in its meaning, that is, a previously overlooked or unappealing offering - Zipcar becomes so popular that it disfavors a previously appealing service - Taxi? All things considered and taking into account Kennedy et al.'s model of Category Meaning Construction and its 8 ways of how category meaning can change, it becomes hard to have a clear answer to whether SE is a straitjacket or an ingredient of creativity in the definition of organizational identity. Meaning: it becomes hard to clearly answer each of the 8 questions above. It's difficult to positively say that SE is acting as a mere straitjacket in the definition of organizational identity. However, given that all 8 questions have, at this moment in time of the evolution of SE, an open answer, one may deduce that, for now, it may only have a role as an ingredient of creativity, which, one the other hand, turns SE as acting as a general ambiguous category enabling divergence in identities and business models. There isn't a well-defined, restricted "SE category" if one takes into account Kennedy et al.'s model of Category Meaning Construction. There currently still are rising many disruptive activities and businesses which are very difficult to frame them within a specific existent category (ex: Zipcar vs Taxi in the transportation sector. Do they belong to the same "focal category", or are they two distinct categories? The same co-relation analysis should be put into perspective regarding the other 3 prototypical organizations - Airbnb, TimeBanks and Make: makerspaces - in terms of their respective sector);

Having Lounsbury's and Rao's (2004) work as a reference, the results of the present study do not show any concrete answers, thus, leaving three open questions (maybe for future research opportunities) - (1) Is SE a "cultural construction" implicated in system of power? That is: will its durability last as long as its dominant producers (prototypes) compel industry media to maintain them?; (2) Without media attention, mediation, and their role as a platform for marketing spreading, will our current notion of SE as a "supposed" category wane and, thus, vanish?; (3) Based on Lounsbury's and Rao's findings, one should ask: is SE (the conceptualization of it and its growing referring and discussion over the last decade or so) a mere and harsh result of industry politics?;

SE firms seem to be hybrid. In the sense that there is a "head-modifier" structure when one category anchors cognition but is modified by features of the other. Example: Zipcar is a type of "transportation service" (the "focal category" or the "header" category, which anchors perceptions of what "transportation service" is), that is modified by features of the other category (the modifier). This other category is: "web 2.0 (mobile app) service" that apparently is less expensive, more convenient and fast in having access to, "presumably" providing a better overall experience to its external audience (consumers). Findings from Wry et al.'s (2014) study leads us to extrapolate that, for example, Zipcar and Airbnb may have been rewarded (ongoing process) or even punished by external audiences (being: consumers, investors, governmental officials, civil society in general) for hybridization contingent on how they mixed "transportation/accommodation", "innovation" and "technology". In general terms, these examples of SE services and activities (Zipcar, Airbnb, TimeBanks and Make: makerspaces) have largely been rewarded by customers over the last years, since their adherence to them has undoubtedly increased, but also been punished in some cases by external audiences: (i) taxi driver's community (its "fight" against Uber, for example) and (ii) governmental officials (Airbnb, for example, was forbidden in Berlin, Germany, in 2016). If one takes into consideration Wry et al.'s findings, that hybridization may indeed have a positive effect on audiences, then one may confirm that, at least from a consumer's perspective, SE firms such as Zipcar and Airbnb have been legitimized and not overlooked or devalued by them;

Bearing in mind Navis' and Glynn's (2010) determinants for legitimation, our results show that 4 out of 5 of those are present in the SE case, thus revealing that there is a pattern path of progressive legitimacy granting in consolidating its place as a category. Recalling the determinants: (1) Sameness (or Close Substitution) - there are a number of services that are perceived to be of the same type in satisfying market demand that may be grouped together as members of that same category. Ex: Schor's peer-to-peer, for-profit services (Relay Rides and Uber - both in the transportation sector); (2) Distinctiveness - there is a distinctiveness of the members of the SE category. Ex: Schor's peer-to-peer and business-topeer, for-profit services (Airbnb and Zipcar - accommodation and transportation sectors, respectively); (3) Credibility stakeholders (scientific community, customers, investors, media, other analysts and other interested audiences), actors external to the category are judging the feasibility, appropriateness and giving credibility to products and services labelled as SE ones; (4) Cognitive legitimation - stakeholders, the public in general are increasingly becoming familiarized with products and services associated to what has been labelled as SE ones; (5) However, the determinant of Sociopolitical legitimation is still under construction - SE companies are presently facing milestone challenges in gaining legitimation from governmental officials and regulators (Ex: Airbnb's prohibition in Berlin, Germany, and the taxi driver's community "fight" against Uber); 
The results of our study (data shown in Tables 1 to 7) also meet Tripsas' (cited in Navis \& Glynn, 2010) foundation that the legitimation construct is a complex social process involving both entrepreneurial organizations - in our case: Airbnb, Zipcar, TimeBanks and Make: makerspaces - and prospective resource providers (stakeholders), such as investors, analysts, customers, media, and other interested audiences, in the social construction of a market category's meaning, the formation of categorical and organizational identities, and perceptions about the viability of the business model;

Also, meeting Zuckerman's (1999, cited in Navis \& Glynn, 2010) findings, our study confirms that audiences (stakeholders) have an absolutely vital influence in assessing the viability of SE and its organizations and can grant or withhold legitimacy to them.

\section{Conclusion and Limitations}

In a first instance, from a perspective of the evolution of the identity claims (self-referential) of Airbnb, Zipcar, TimeBanks and Make: makerspaces, our findings show that none of them identify themselves as belonging to a SE category, thus, revealing that SE hasn't been having a significant role in establishing the identity of those organizations. In a second instance, from a perspective of the evolution of legitimacy granting by stakeholders to the same set of prototypical organizations, we complementarily were able to identify how a vast range of stakeholders, external actors and interested audiences have been granting legitimacy to them. Being a complex social process involving both entrepreneurial organizations and stakeholders, such as investors, analysts, customers, media, and other interested audiences, our study confirms that stakeholders have an critical influence in assessing the viability of SE and its organizations and can grant or withhold legitimacy to them. In this respect, there is a clear pattern path of a progressive legitimacy granting in establishing SE as a category (4 out of 5 identified determinants are present). It has been a process contoured by complex, dense and multifaceted evolutionary granting events. It becomes clearer that SE has been having a positive effect in establishing the identity of organizations belonging to the field. A comprehensive range of stakeholders -scientific community, investors, analysts, customers, media, and other interested audiences - have been studying, analysing, discussing, debating, put into perspective, investing, and adhering to SE products and services (including Airbnb's, Zipcar's, TimeBanks' and Make: makerspaces' ones) in a progressive manner along the years. Further, based on the studies of category creation discussed earlier, we generally conclude that the process of creating SE as a category is one that that goes beyond a mere rigid, constraint, straitjacket categorical model. That is, at least for now, SE has only been having a role as an ingredient of creativity, which, one the other hand, turns SE as acting as a general ambiguous category enabling divergence in identities and business models. Moreover, SE prototypical organizations seem to be hybrid, in the sense that there is a "headmodifier" structure when one category anchors cognition but is modified by features of the other. Our findings lead us, on the other hand, to extrapolate that prototypical SE services and activities have largely been rewarded by customers over the last years, since their adherence to them has undoubtedly increased, but they also have been punished by other external audiences, namely, governmental officials and regulators for the hybridization contingent on how they mixed "transportation/accommodation", "innovation" and "technology", thus, not providing Sociopolitical legitimation to them. Examples of this are (i) the taxi driver's community "fight" against Uber and (ii) governmental officials in delaying clear regulations for SE companies, such as Airbnb, to legitimately act in the market zone.

Resuming, although each stakeholder gives SE prototypical organizations heterogeneous, diverse, very specific, different, well-defined and sometimes divergent contours (thus, each of them providing SE various activities a "straitjacket" dimension, in the sense of confining them to very specific spheres of action. Example: Schor's confinement of SE activities into four main archetypes - peer-to-peer, for-profit; business-to-peer, for-profit activity; peer-to-peer, non-profit and business-to-peer, non-profit) and as it shows signs of still being a mutant and evolving process of identity creation, SE seems to be countered by an ingredient of creativity in the definition of organizational identity more than a "straightjacket" force. Stakeholders, in general terms, broach and define SE in various forms and in their very own way. That is the same to say that, taking into consideration the evidence collected in this study, yes SE is constraining the identity claims for the stake of legitimacy granting and it still is acting as a general ambiguous category enabling divergence in identities and business models.

This study provides a number of contributions to extant literature. From an academic perspective, it offers a new layer on framing a detailed understanding of the SE field in its maturing dimension, thus, meeting Mair and Reischauer's (2017) call for studying the SE, unpack and make sense of an inspiring and complex phenomenon and thereby to advance and refine existing theory. From a methodological perspective, this paper contributes in making an historical analysis of the establishment of organizational identity of four prototypical SE organizations, considering identify claims and legitimacy 
granting. From a practical point of view, it can serve as a guide (for new up-coming SE aspiring organizations/entities, for example) to (i) understand what it takes to be considered and legitimated as an SE activity and (ii) get a deeper glance over how socially complex it is to gain legitimation from stakeholders, as it interdependently involves entrepreneurial organizations and prospective resource providers (such as investors, analysts, customers, media, and other interested audiences) in the social construction of their market category meaning, the formation of their categorical and organizational identities, and perceptions about the viability of their business models.

This study is not without limitations. At the forefront, it may be criticized for being too descriptive, in the sense that there wasn't any experimental design involved in it. The aim was, nevertheless, to make an historical analysis of the establishment of SE organizational identity, considering both identify claims and legitimacy granting, thus, it would always have by default a descriptive dimension associated to it. Second, regarding the chosen sample - just four prototypical organizations -, it would had enlarged the consistency and robustness of our analysis and consequent findings if we would had added more organizations. In this respect, however, our aim was to primary analyze all four Schor's four SE architypes of activities, so no activity would be left behind. Having that as a premise, we then chose one organization per architype of activity and, consequently, came up with Airbnb, Zipcar, TimeBanks and Make: makerspaces. Third, in terms of the business-to-peer, for-profit activity option chosen, we reckon that the study would probably have gained more visibility in case, for example, we had opted for the prototypical organization of Uber instead of Zipcar, mostly for the simple fact that the first has been caught greater attention from stakeholders and audiences, recently. In this respect, yes, we contemplated the first one, but, unfortunately, its website wasn't and still isn't running in Portugal due to regulatory constraints, thus, not allowing to obtain direct identity claims data. Fourth, there may certainly be more stakeholders that could well be included in our analysis list of the evolution of legitimacy granting. However, our objective wasn't to make a systematic literature review nor include all existing stakeholders, but rather to analyze the maximum spectrum of stakeholders as possible.

\section{References}

[1] Airbnb (2016) Airbnb's 2016 highlights and 2017 trends we're watching. (Online) Available from: https://www.airbnbcitizen.com/airbnbs-2016-highlights-and-2017-trends-were-watching/ (Accessed: 11th July 2017).

[2] Airbnb (2017) Fast Facts. The Airbnb Story. (Online) Available from: https://press.atairbnb.com/fast-facts/ (Accessed: 31st July 2017).

[3] Aldrich, H. E. \& Fiol, C. M. (1994) Fools rush in? The Institutional context of industry creation. Academy of Management Review, 19(4), 645.

[4] ATINER (2017) A Panel on The Sharing Economy as part of the 4th Annual International Conference on Social Sciences. (Online) Available from: https://www.atiner.gr/2017Conferences (Accessed: $5^{\text {th }}$ May 2017).

[5] Bardhi, F. \& Eckhardt, G. (2012) Access based consumption: The case of car sharing. Journal of Consumer Research, 39, 881-898.

[6] Barsalou, L. W. (1983) Ad hoc categories. Memory \& Cognition, 11, 211-27.

[7] Bauwens, M. (2005) The political economy of peer production. (Online) Available from: http://www.informatik.unileipzig.de/ graebe/Texte/Bauwens-06.pdf (Accessed: 3rd April 2017).

[8] BBC News (2014) JustPark and the sharing economy. (Online) Available from: http://www.bbc.com/news/technology28686606 (Accessed: 11 $1^{\text {th }}$ August 2017).

[9] Belk, R. (2014) You are what you can access: Sharing and collaborative consumption online. Journal of Business Research, $67,1595-1600$.

[10] Benkler, Y. (2002) Coase's Penguin, or, Linux and The Nature of the Firm. Yale Law Journal, pp. 369-446.

[11] Bizz Grid (2017) Sharing Economy and Earnings on Demand. (Online) Available from: https://bizzgrid.com/talks/earnings-ondemand-17 (Accessed: 17 th August 2017).

[12] Bloomberg, (2016) The Sharing Economy Doesn't Share the Wealth. (Online) Available from: https://www.bloomberg.com/news/articles/2016-04-06/the-sharing-economy-doesn-t-share-the-wealth (Accessed: 11th August 2017).

[13] Bonciu, F. \& Bâlgar, A. C. (2016) Sharing Economy as a Contributor to Sustainable Growth. An EU Perspective. Romanian Journal of European Affairs, 16(2), 36-45.

[14] Botsman, R. \& Rogers, R. (2010) What's mine is yours: The rise of collaborative consumption. New York: Harper Collins.

[15] Bradley, K. \& Pargman, D. (2017) The sharing economy as the commons of the 21 st century. Cambridge Journal of Regions Economy and Society, 10(2), 231-247.

[16] Breakers Makers (2015) The Sharing Economy \& On Demand Conference. (Online) Available from: http://www.breakerstomakers.com (Accessed: $7^{\text {th }}$ August 2017). 
[17] Buckingham, D. (2017) Media and the sharing economy. (Online) Available from: https://davidbuckingham.net/2017/05/02/media-and-the-sharing-economy/ (Accessed: 11 th August 2017).

[18] CBS (2017) Inside China's booming sharing economy. (Online) Available from: http://www.cbsnews.com/news/china-popularsharing-economy-exploding-didi/ (Accessed: 11th August 2017).

[19] Cheng, M. (2016) Sharing economy: A review and agenda for future research. International Journal of Hospitality Management, 57, 60-70.

[20] CNBC (2014) Sharing Economy. (Online) Available from: https://www.cnbc.com/sharing-economy/?page=4 (Accessed: $7^{\text {th }}$ August 2017).

[21] CNN (2015) Sharing is daring: mapping the disruption economy. (Online) Available from: http://edition.cnn.com/2014/09/19/business/sharing-economy-guide/index.html (Accessed: 11 th August 2017).

[22] Cohen, B. \& Kietzmann, J. (2014) Ride On! Mobility Business Models for the Sharing Economy. Journal of Organization \& Environment, 27 (3), 279-296.

[23] Crunchbase (2017a) Airbnb - Investors. (Online) Available from: https://www.crunchbase.com/organization/airbnb\#/entity (Accessed: $7^{\text {th }}$ August 2017).

[24] Crunchbase (2017b) Zipcar - Investors. (Online) Available from: https://www.crunchbase.com/organization/zipcar\#/entity (Accessed: $7^{\text {th }}$ August 2017).

[25] Davis, M. (2017) A Brief History of Makerspaces. (Online) Available from: https://curiositycommons.wordpress.com/a-briefhistory-of-makerspaces/ (Accessed: 31st July 2017).

[26] Dubois, E., Schor, J., \& Carfagna, L. (2014) New Cultures of Connection in a Boston Time Bank. In J. Schor \& C. Thompson (Eds.), Practicing Plenitude. New Haven: Yale University Press.

[27] Durand, R., \& Paolella, L. (2013) Category stretching- Reorienting research on categories in strategy, entrepreneurship, and organization theory. Journal of Management Studies, 50(6), 1100-1123.

[28] EC (2016) Scoping the Sharing Economy: Origins, Definitions, Impact and Regulatory Issues. JRC Technical Reports. European Commission. (Online) Available from: https://ec.europa.eu/jrc/sites/jrcsh/files/JRC100369.pdf (Accessed: $3^{\text {rd }}$ April 2017).

[29] Eha, B. P. (2013) Zipcar Timeline: From Business Idea to IPO to $\$ 500$ Million Buyout. (Online) Available from: https://www.entrepreneur.com/article/225399 (Accessed: 1st August 2017).

[30] El Mundo (2016) Al menos 9.786 anuncios en Airbnb sin licencia en Barcelona. (Online) Available from: http://www.elmundo.es/economia/2016/08/15/57b046bfca4741ce038b4577.html (Accessed: $11^{\text {th }}$ August 2017).

[31] ESA (2016) Digital Matching Firms: A New Definition in the "Sharing Economy" Space. (Online) Available from: http://www.esa.doc.gov/reports/digital-matching-firms-new-definition-"sharing-economy"-space (Accessed: $3^{\text {rd }}$ April 2017).

[32] ESCP Europe (2016) Second International Workshop on the Sharing Economy. (Online) Available from: http://shareeco.strikingly.com/ (Accessed: $11^{\text {th }}$ August 2017).

[33] Fortune (2015) Sharing Economy. As "sharing economy" fades, these 2 phrases are likely to replace it. (Online) Available from: http://fortune.com/2015/07/29/sharing-economy-chart/ (Accessed: 11 th August 2017).

[34] Frenken, K. \& Schor, J. (2017) Putting the sharing economy into perspective. Environmental Innovation and Societal Transitions, 23, 2-10.

[35] FT (2016a) Regulators should not rush to curb Uber and Airbnb. (Online) Available from: https://www.airdna.co/research (Accessed: $11^{\text {th }}$ August 2017).

[36] FT (2016b) FT Sharing Economy Summit Europe 2016 - Achieving stability among growing regulation. (Online) Available from: https://live.ft.com/Events/2016/FT-Sharing-Economy-Summit-Europe-2016 (Accessed: 11 ${ }^{\text {th }}$ August 2017).

[37] FTC (2015a) FTC The "Sharing" Economy Workshop transcript segment 3 - June 9, 2015. Washington D.C.: Federal Trade Commission. (Online) Available from: https://www.ftc.gov/system/files/documents/videos/sharing-economy-workshop-part2/ftc_sharing_economy_workshop_-_transcript_segment_3.pdf (Accessed: 3rd April 2017).

[38] FTC (2015b) FTC The "Sharing" Economy Workshop transcript segment 4 - June 9, 2015. Washington D.C.: Federal Trade Commission. (Online) Available from: https://www.ftc.gov/system/files/documents/videos/sharing-economy-workshop-part2/ftc_sharing_economy_workshop_-_transcript_segment_4.pdf (Accessed: $3^{\text {rd }}$ April 2017).

[39] FTC (2015c) The "Sharing" Economy Workshop transcript segment 2 - June 9, 2015. Washington D.C.: Federal Trade Commission. (Online) Available from: https://www.ftc.gov/system/files/documents/videos/sharing-economy-workshop-part2/ftc_sharing_economy_workshop_-_transcript_segment_2.pdf (Accessed: $3^{\text {rd }}$ April 2017).

[40] Frenken, K., Meelen, T., Arets, M. \& van de Glind, P. (2015) Smarter regulation for the sharing economy. The Guardian. (Online) Available from: http://www.theguardian.com/science/political-science/2015/may/20/smarter-regulation-for-thesharing-economy (Accessed: $3^{\text {rd }}$ April 2017).

[41] Gansky, L. (2010) The mesh: Why the future of business is sharing. New York: Portfolio Penguin.

[42] Glynn, M. A., \& Navis, C. (2013) Categories, identities, and cultural classification: Moving beyond a model of categorical constraint. Journal of Management Studies, 50(6), 1124-1137. 
[43] Hamari, J., Sjoklint, M. \& Ukkonen, A. (2015) The sharing economy: Why people participate in collaborative consumption. Journal of the Association for Information Science and Technology, n/a-n/a. doi: 10.1002/asi.23552.

[44] Hira, A. \& Reilly, K. (2017) The Emergence of the Sharing Economy: Implications for Development. Journal of Developing Societies, 33, 2, 1-16.

[45] Humboldt-Universität zu Berlin (2016) 7th International Conference on Corporate Sustainability and Responsibility - CSR In an Age of Digitization. (Online) Available from: https://www.csr-hu-berlin.org/content/about (Accessed: 11th August 2017).

[46] Liftshare (2015) Oxford Dictionary adds sharing economy and ridesharing descriptions. (Online) Available from: http://blog.liftshare.com/industry/oxford-dictionary-adds-sharing-economy-and-ridesharing-descriptions (Accessed: $3^{\text {rd }}$ April 2017).

[47] Kaufman, A. C. (2016) Zipcar Is Renting Its Vehicles Out For Free On Election Day. (Online) Available from: http://www.huffingtonpost.com/entry/zipcar-election-day_us_581cc14ae4b0d9ce6fbb8fde (Accessed: 1st August 2017).

[48] Kennedy, M. T. (2008) Getting counted: Markets, media, and reality. American Sociological Review, 73(2), 270-295.

[49] Kennedy, M. T. \& Fiss, P. C. (2013) An ontological turn in categories research - From standards of legitimacy to evidence of actuality. Journal of Management Studies, 50(6), 1138-1154

[50] Kennedy, M. T., Lo, J., \& Lounsbury, M. (2010) Category currency - A framework for analyzing the effects of meaning construction process. Research in the Sociology of Organizations, 31, 369-397.

[51] Kim, J., Yoon, Y. \& Zo, H. (2015) Why people participate in the Sharing Economy: A Social Exchange Perspective. Pacific Asia Conference on Information Systems (PACIS). PACIS 2015 Proceedings.

[52] Knote, R. \& Blohm, I. (2016) Deconstructing the Sharing Economy: On the Relevance for IS Research. Konferenz Mobilitait \& Digitalisierung (MMS 2016).

[53] Lee, Y., Lee, S. \& Ryu, M. H. (2016) A Study on Factors Influencing Consumers' Information Needs for Sharing Economy Service. (Online) Available from: https://www.researchgate.net/publication/315930853_A_Study_on_Factors_Influencing_Consumers'_Information_Needs_fo r_Sharing_Economy_Service (Accessed: 13 th August 2017).

[54] Lessig, L. (2008) Remix: Making art and commerce thrive in the hybrid economy. New York: Penguin.

[55] Liftshare blog (2015) Oxford Dictionary adds sharing economy and ridesharing descriptions. (Online) Available from: http://blog.liftshare.com/industry/oxford-dictionary-adds-sharing-economy-and-ridesharing-descriptions (Accessed: $3^{\text {rd }}$ April 2017).

[56] Lounsbury, M. \& Rao, H. (2004) Sources of durability and change in market classifications - A study of the reconstitution of product categories in the American mutual fund industry, 1944-1985. Social Forces, 82(3), 969-999.

[57] Lund University (2017) Fourth International Workshop on the Sharing Economy. (Online) Available from: http://www.iiiee.lu.se/article/the-4th-international-workshop-on-the-sharing-economy (Accessed: 17 th August 2017).

[58] Lovins, H. \& Cohen, B. (2011) Climate capitalism: Capitalism in the age of climate change. New York, NY: Hill \& Wang.

[59] Macalister, T. (2013) Mergers and Acquisitions. Avis Budget buys Zipcar for $\$ 500 m-a$ 50\% premium to its share value. (Online) Available from: https://www.theguardian.com/business/2013/jan/02/avis-budget-buys-zipcar-share-value (Accessed: 1st August 2017).

[60] Maddox Events (2016) The Sharing Economy Conference 2016. (Online) Available from: http://maddoxevents.wixsite.com/maddox-2 (Accessed: 1st August 2017).

[61] Mair, J. \& Reischauer, G. (2017) Capturing the dynamics of the sharing economy: Institutional research on the plural forms and practices of sharing economy organizations. Technological Forecasting and Social Change. ISSN 0040-1625.

[62] Make: makerspaces (2017) About Us. (Online) Available from: http://spaces.makerspace.com/ (Accessed: 1st August 2017).

[63] Meelen, T. \& Frenken, K. (2015) Stop Saying Uber Is Part Of The Sharing Economy. FastCompany. (Online) Available from: http://www.fastcoexist.com/3040863/stop-saying-uber-is-part-of-the-sharing-economy (Accessed: $3^{\text {rd }}$ April 2017).

[64] Milken Institute (2016) Is the Sharing Economy the New Normal? (Online) Available from: http://www.milkeninstitute.org/events/conferences/global-conference/2016/panel-detail/6223 (Accessed: 1st August 2017).

[65] Munoz, P. \& Cohen, B (2017) Mapping out the Sharing Economy: A Configurational Approach to Sharing Business Modeling. Technological Forecasting and Social Change. ISSN 0040-1625.

[66] Navis, C., Fisher, G., Raffaelli, R., Glynn, M. A. \& Watkiss, L. (2012) The market that wasn't: the non-emergence of the online grocery category. Proceedings of the New Frontiers in Management and Organizational Cognition Conference. National University of Ireland Maynooth.

[67] Navis, C. \& Glynn, M. A. (2010) How new market categories emerge: Temporal dynamics of legitimacy, identity, and entrepreneurship in satellite radio, 1990-2005. Administrative Science Quarterly, 55, 439-471.

[68] NYU (2012) Maker Market Study: An In-depth Profile of Makers at the Forefront of Hardware Innovation. (Online) Available from: http://www.nyu.edu/social-entrepreneurship/speaker_series/pdf/Maker Market Study FINAL.pdf (Accessed: $11^{\text {th }}$ August 2017).

[69] OECD. (2015a) Digital Economy Outlook 2015. Paris: OECD Publishing. 
[70] OECD. (2015b) New Form of Work in the Sharing Economy. Background for Discussion. Paris: OECD, Working Party on Measurement and Analysis of the Digital Economy, DSTI/ICCP/IIS (2015)3.

[71] Owyang, J. (2013) The Collaborative Economy. (Online) Available from: https://www.slideshare.net/Altimeter/thecollaborative-economy (Accessed: $3^{\text {rd }}$ April 2017).

[72] Penn, J. \& Wihbey, J. (2016) Uber, Airbnb and consequences of the sharing economy: Research roundup. (Online) Available from: http://journalistsresource.org/studies/economics/business/airbnb-lyft-uber-bike-share-sharing-economy-researchroundup (Accessed: $18^{\text {th }}$ June 2016).

[73] PwC (2015) The Sharing Economy. (Online) Available from: https://www.pwc.com/us/en/technology/publications/assets/pwcconsumer-intelligence-series-the-sharing-economy.pdf (Accessed: 18 th June 2016).

[74] Rehder, B. (2003a) Categorization as causal reasoning. Cognitive Science, 27, 709-48.

[75] Rehder, B. (2003b) A causal-model theory of conceptual representation and categorization. Journal of Experimental Psychology - Learning Memory and Cognition, 29, 1141-59.

[76] Rosch, E. \& Mervis, C. B. (1975) Family resemblances: studies in internal structure of categories. Cognitive Psychology, 7 , 573-605.

[77] Ryerson University (2016) The Sharing Economy and the Future of Work. (Online) Available from: http://www.ryerson.ca/clmr/publications/2016_10_24/ (Accessed: 6 $6^{\text {th }}$ August 2017).

[78] Schor, J. B. (2014) Debating the Sharing Economy. (Online) Available from: http://www.tellus.org/pub/Schor_Debating_the_Sharing_Economy.pdf (Accessed: 16 $6^{\text {th }}$ August 2015).

[79] Schor, J. (2015) Getting Sharing Right. Contexts, 14(1), 14-15.

[80] Schor, J. \& Fitzmaurice, C. (2015) Collaborating and Connecting: The emergence of the sharing economy. Handbook of Research on Sustainable Consumption (pp. 410-425). Cheltenham, UK: Edward Elgar.

[81] Schor, J., Fitzmaurice, C., Carfagna, L. \& Will-Attwood, C. (2014) Paradoxes of Openness and Distinction in the Sharing Economy. Boston: Boston College.

[82] Shidler College of Business - University of Hawaii (2017) 50th Hawaiian International Conference on System Sciences (HICSS). (Online) Available from: http://shidler.hawaii.edu/events/2017/01/04/hawaii-international-conference-on-systemsciences-50th-anniversary (Accessed: $17^{\text {th }}$ August 2017).

[83] Silver, J. (2013) The sharing economy: a whole new way of living. (Online) Available from: http://www.theguardian.com/technology/2013/aug/04/internet-technology-fon-taskrabbit-blablacar (Accessed: 23 ${ }^{\text {rd }}$ August 2014).

[84] Smith, E. B. (2011) Identities as Lenses: How Organizational Identity Affects Audiences' Evaluation of Organizational Performance. Administrative Science Quarterly, 56, 61-94.

[85] Stead, J. G. \& Stead, W. E. (2013) The coevolution of sustainable strategic management in the global marketplace. Organization \& Environment, 26, 162-183.

[86] Stone, B. (2016) The Upstarts: How Uber, Airbnb, and the Killer Companies of the New Silicon Valley Are Changing the World. Little, Brown.

[87] Sundararajan, A. (2016) The Sharing Economy: The End of Employment and the Rise of Crowd-Based Capitalism. Cambridge, MA: The MIT Press.

[88] Switzer Foundation (2013) Sharing Economy Conference: Boston with Julia Ledewitz. (Online) Available from: http://www.switzernetwork.org/events/sharing-economy-conference-boston-julia-ledewitz (Accessed: $6^{\text {th }}$ August 2017).

[89] The Economist (2016) The sharing economy brings tycoon lifestyles within reach of some. (Online) Available from: https://www.economist.com/news/business-and-finance/21710767-thanks-companies-such-netjets-getmyboat-andthirdhomecom-merely-rich-can-upgrade (Accessed: 11 th August 2017).

[90] The New York Times (2015) New Worry for Home Buyers: A Party House Next Door. (Online) Available from: https://www.nytimes.com/2015/10/10/your-money/new-worry-for-home-buyers-a-party-house-next-door.html?_r=0 (Accessed: 11'th August 2017).

[91] TimeBanks (2017a) About. (Online) Available from: https://timebanks.org/about/ (Accessed: 1st August 2017).

[92] TimeBanks (2017b) Directory of TimeBanks. (Online) Available from: http://community.timebanks.org/ (Accessed: $9^{\text {th }}$ August 2017).

[93] Universidade do Algarve (2017) Sharing Economy - Collaborative Consumption: Current trends and visions in key economic areas for Germany and Southern Europe. (Online) Available from https://www.jiscmail.ac.uk/cgibin/webadmin?A2=TOURISM-CULTURE-POLICY;58f58de3.1702 (Accessed: 18 th August 2017).

[94] University of Southampton (2016) Third International Workshop on the Sharing Economy. (Online) Available from: https://www.southampton.ac.uk/wsa/news/events/iwse/index.page (Accessed: $6^{\text {th }}$ August 2017).

[95] U.S. House (2015) Swawell, Issa Announce the Sharing Economy Caucus. (Online) Available from: https://swalwell.house.gov/media-center/press-releases/swalwell-issa-announce-sharing-economy-caucus (Accessed: $3^{\text {rd }}$ April 2017). 
[96] Utrecht University (2015) First International Workshop on the Sharing Economy. (Online) Available from: https://www.uu.nl/en/IWSE2015 (Accessed: 1st August 2017).

[97] Wry, T., Lounsbury, M. \& Jennings, P. D. (2014) Hybrid vigor- Securing venture capital by spanning categories in nanotechnology. Academy of Management Journal, 57(5), 1309-1333.

[98] WSJ (2015) Airbnb Crimps Hotels' Power on Pricing. Lodging listings surged for pope's U.S. visit, challenging hotel industry. (Online) Available from: https://www.wsj.com/articles/airbnb-crimps-hotels-power-on-pricing-1443519181 (Accessed: 1st August 2017).

[99] Yang, S., Song, Y., Chen, S. \& Xia, X. (2017) Why are customers loyal in sharing-economy services? A relational benefits perspective. Journal of Services Marketing, Vol. 31, Issue: 1, 48-62.

[100] Zifkin, A. (2015) Interview. In: Politik Media Inc. 2015. (Online) Available from: http://www.politik.io/articles/the-sharingeconomyl (Accessed: $16^{\text {th }}$ June 2016).

[101]Zipcar (2015) Ziptopia. 15 Years of Zipcar. One Epic Ride. [Infographic]. (Online) Available from: http://www.zipcar.com/ziptopia/inside-zipcar/15-years-of-zipcar-one-epic-ride-infographic (Accessed: 11th August 2017).

[102] Zipcar (2017a) About us. (Online) Available from: http://www.zipcar.com/about (Accessed: 1st August 2017).

[103] Zipcar (2017b) Ziptopia. 10 Things You Didn't Know About Zipcar (Okay, More Than 10) [Infographic]. (Online) Available from: http://www.zipcar.com/ziptopia/inside-zipcar/history-of-zipcar-infographic (Accessed: $6^{\text {th }}$ August 2017). 